\title{
Role of RhoC in cancer cell migration
}

\author{
Yingyue Lou', Yuhan Jiang ${ }^{1}$, Zhen Liang ${ }^{2}$, Bingzhang Liu' ${ }^{1}$ Tian Li ${ }^{1 *}$ and Duo Zhang ${ }^{1 *}$ (D)
}

\begin{abstract}
Migration is one of the five major behaviors of cells. Although RhoC — a classic member of the Rho gene family —was first identified in 1985, functional RhoC data have only been widely reported in recent years. Cell migration involves highly complex signaling mechanisms, in which RhoC plays an essential role. Cell migration regulated by RhoC_of which the most well-known function is its role in cancer metastasis - has been widely reported in breast, gastric, colon, bladder, prostate, lung, pancreatic, liver, and other cancers. Our review describes the role of RhoC in various types of cell migration. The classic two-dimensional cell migration cycle constitutes cell polarization, adhesion regulation, cell contraction and tail retraction, most of which are modulated by RhoC. In the three-dimensional cell migration model, amoeboid migration is the most classic and well-studied model. Here, RhoC modulates the formation of membrane vesicles by regulating myosin $I I$, thereby affecting the rate and persistence of amoeba-like migration. To the best of our knowledge, this review is the first to describe the role of RhoC in all cell migration processes. We believe that understanding the detail of RhoC-regulated migration processes will help us better comprehend the mechanism of cancer metastasis. This will contribute to the study of anti-metastatic treatment approaches, aiding in the identification of new intervention targets for therapeutic or genetic transformational purposes.
\end{abstract}

Keywords: RhoC, Cell migration, Three-dimensional, Polarization, Adhesion, Amoeboid

\section{Background}

Migration is one of the most desirable behavioral attributes of cells, which has been observed in most animal cells and several unicellular organisms, such as amoebae [1]. Cell migration is essential in immune monitoring, wound repair, and embryonic development. Abnormal cell migration is a hallmark of various pathologies such as cancer metastasis and chronic inflammation [1]. Generally, when studying cellular migration behavior, the migration mechanism adopted by cells is classified as either two- (2D) or three-dimensional (3D) migration under in vitro culture and in vivo conditions, respectively [2-4]. According to classic two-dimensional cell migration cycle $[5,6]$, cell migration is initiated with morphological polarization, in which after cells extend a protrusion in the direction of movement and forms a

*Correspondence: 5232942It@sina.com; zhangduo@jlu.edu.cn

${ }^{1}$ Department of Plastic and Reconstructive Surgery, The First Hospital of Jilin University, Changchun, Jilin, China

Full list of author information is available at the end of the article new cell-matrix adhesion between the protrusion and the cell substrate. The cell body then contracts and moves forward, finally ending the cycle by retracting adhesions at the rear [7]. In recent years, as research has intensified, the essence of cell migration-namely $3 \mathrm{D}$ migration that includes three modes: mesoscopic, lobopodial, and amoeboid migration-has surfaced. In 3D migration, the cell interacts with the surrounding matrix, adjusts the migration mode according to the changes of the surrounding environment and itself, and changes flexibly in the three modes $[8,9]$. Effective migration requires the coordinated dynamics of the cellular components involved, and these structures are strictly regulated by several signals [10]. To date, vital proteins related to cancer cell migration have been identified to include RhoA, RhoB, RhoC, Cdc42, Rac, and other members of the Rho GTPase family [10-12], the Ras superfamily [13, 14], the WASP/WAVE family [15-19], the Scrib complex [20-23], and Par complex [24, 25], PI3Ks [26] and PTEN $[27,28]$, PKCs [29], FAK [30, 31], ERK [32], and Src [33, 34], among others. Herein, the role of RhoC in cancer original author(s) and the source, provide a link to the Creative Commons licence, and indicate if changes were made. The images or other third party material in this article are included in the article's Creative Commons licence, unless indicated otherwise in a credit line to the material. If material is not included in the article's Creative Commons licence and your intended use is not permitted by statutory regulation or exceeds the permitted use, you will need to obtain permission directly from the copyright holder. To view a copy of this licence, visit http://creativecommons.org/licenses/by/4.0/. The Creative Commons Public Domain Dedication waiver (http://creativeco mmons.org/publicdomain/zero/1.0/) applies to the data made available in this article, unless otherwise stated in a credit line to the data. 
cell migration is of particular interest. RhoC reportedly affects cell movement by influencing the activities of actin and myosin, and cell adhesion [35], thereby affecting the process of cancer metastasis. According to the existing literature, it plays an important role in many cancers, such as influencing angiogenesis in bladder cancer [36] and tumorigenesis and epithelial-mesenchymal transition (EMT) in osteosarcoma [37], regulating the emergence of radioresistance in cervical cancer [38], and affecting prostate cancer treatments that target the glutamine pathway [39]. Certainly, its most significant role is promoting metastasis in breast [40-42], gastric [43, 44], colon [45, 46], bladder [47], prostate [48, 49], lung [50], pancreatic [51], liver [52] and other cancers. A recent study on prostate cancer has excitingly announced that vaccination against RhoC could potentially delay or prevent cancer recurrence and metastasis [53]. Additionally, murine studies have shown that $\mathrm{RhoC}$ is not essential to embryogenesis, but essential for metastasis, making it a possible target for gene modification [54]. To equip researchers with a more intuitive and detailed understanding of RhoC-related migration, this paper reviews the specific mechanism of RhoC involvement in each process or mode of migration. It also discusses the direction of future research on $\mathrm{RhoC}$ and its prospect as a target for anti-metastasis therapy.

\section{Main text}

\section{The Rho GTPase family}

Rho GTPases are small signaling G proteins-also known as small GTPases, small G-proteins, or the Ras superfamily-that regulate the cytoskeleton, affect cell mobility, polarity and division, and play an important role in cell migration and invasion [55], as seen in Table 1. In humans, this family consists of twenty members, divided into eight different subfamilies and classified as either classic (typical) or atypical [56]. Classical Rho GTPases, including Rac, Rho, Cdc42, and the RhoF/RhoD subfamilies, are regulated by Rho-specific guanine nucleotide exchange factors (GEFs) and GTPase activating proteins (GAPs), which drive the switch between GTP- and GDPbound states. GEF catalyzes the transition between GTP and GDP, thereby activating GTPase, whereas GAPs increase the intrinsic GTP hydrolysis rate of GTPases, thereby inactivating them $[55,57]$. Atypical Rho family members include Rnd, RhoBTB, RhoU/V, and RhoH subfamilies, which are not regulated by GEF or GAP, but mainly modulated by GTP and other mechanisms, including post-translational modification [58]. In recent years, the role of the Rho subfamily of Rho GTPases in cell migration, has been widely studied. The Rho subfamily-which includes the highly homologous RhoA, RhoB, and RhoC that share $85 \%$ amino acid sequence identity-is known to regulate actin skeleton dynamics [59], as seen in Fig. 1. Like other GTPases, these Rho isoforms have intrinsic GTPase activity and shuttle between the inactive GDP-bound and active GTP-bound states [60]. However, many studies have shown differentiation of their intracellular distribution and function. For example, RhoA and RhoC are located in the cytoplasm, while RhoB is located in endosomes [61]. RhoA plays a key role in regulating the actomyosin contractility and cell proliferation, whereas RhoB regulates the transport of cytokines and cell survival, and RhoC is more important in cell movement [59]. Each step in the process of cell migration is guided and regulated by a variety of signal molecules. The Rho GTPase family is the most important of these regulators, among which $\mathrm{RhoC}$ has been proven responsible for cytoskeleton recombination and cell movement [35]. In this article, we focus on the specific mechanism by which RhoC influences the process of cell migration.

\section{History of RhoC}

RhoC was first discovered in 1985, when Madaule and Axel isolated a new Ras gene family from the cDNA library of the Aplysia abdominal ganglion, naming it the Rho gene. It has significant homology with the Ras oncogene family and encodes a protein that shares $35 \%$ amino acid resemblance with $\mathrm{H}$-ras [62]. The same research team proceeded to isolate two Rho family members from Saccharomyces cerevisiae and characterized them using DNA sequence analysis. These yeast genes, named Rho1 and Rho2, respectively shared 70 and 57\% identity with those of the marine snail Aplysia, and $53 \%$ identity with each other. Furthermore, knockdown of these genes revealed that, contrary to Rho2, Rho1 was required for cell activity [63]. The authors further examined the Rho gene in humans and rats, and suggested that the human Rho gene potentially consisted of three members [64]. However, due to lack of biological findings, little attention was paid to these discoveries. Then, Yeramian et al. published the nucleotide sequence of human Rho cDNA clone 12 [65], followed by publishing of the coding sequences of clones 6 and 9 the year after, by Chardin et al. Clones 12,6 , and 9 were named RhoA, RhoB, and RhoC, respectively [66]. Chardin et al. further found that the bacterially expressed product of the human $R H O C$ gene is ADP-ribosylated by Clostridium botulinum $\mathrm{C} 3$, and corresponds to the C3 substrate of eukaryotic cells in size, charge, and behavior. When Vero cells were treated with C3, their microfilaments disintegrated and radial symmetry morphology changed, but no direct effect on actin was evident. Therefore, they speculated that the unmodified form of Rho protein may be involved in regulation of 
Table 1 The Rho GTPase family

\begin{tabular}{|c|c|c|c|c|}
\hline Rho GTPase & Subfamily & Intracellular distribution & Major functions in cell migration & References \\
\hline RhoA & Rho & $\begin{array}{l}\text { plasma membrane; } \\
\text { cytoplasm; } \\
\text { nucleus; }\end{array}$ & $\begin{array}{l}\text { Regulate contractility in the cell body; } \\
\text { Regulate membrane protrusion; }\end{array}$ & {$[174-176]$} \\
\hline RhoB & Rho & $\begin{array}{l}\text { plasma membrane; } \\
\text { endosomes; } \\
\text { multivesicular bodies; } \\
\text { nucleus; }\end{array}$ & Affect focal adhesion contacts with the substratum; & {$[177,178]$} \\
\hline RhoC & Rho & cytoplasm; & Restrict the breadth of lamellipodia; & {$[108,179]$} \\
\hline Rac1 & Rac & $\begin{array}{l}\text { plasma membrane; } \\
\text { nucleus; } \\
\text { mitochondria; }\end{array}$ & Stimulate the formation of lamellipodia; & {$[180,181]$} \\
\hline Rac2 & Rac & plasma membrane; & $\begin{array}{l}\text { Regulate actin remodeling; } \\
\text { affect membrane ruffling; }\end{array}$ & {$[182,183]$} \\
\hline Rac3 & $\operatorname{Rac}$ & perinuclear; & $\begin{array}{l}\text { Stimulate the formation of lamellipodia; } \\
\text { affect membrane ruffling; }\end{array}$ & {$[184,185]$} \\
\hline RhoG & $\operatorname{Rac}$ & $\begin{array}{l}\text { plasma membrane; } \\
\text { perinuclear; }\end{array}$ & $\begin{array}{l}\text { Regulate the formation of membrane ruffles, lamellipodia, filopodia, and } \\
\text { microvilli; }\end{array}$ & [186] \\
\hline $\mathrm{Cdc42}$ & Cdc42 & $\begin{array}{l}\text { plasma membrane; } \\
\text { the Golgi apparatus; }\end{array}$ & Regulate the formation of filopodia & {$[187,188]$} \\
\hline RhoJ & $\mathrm{Cdc42}$ & $\begin{array}{l}\text { plasma membrane; } \\
\text { organelle membrane; }\end{array}$ & Regulate the numbers, size and disassembly of focal adhesion; & {$[189,190]$} \\
\hline RhoQ & $\mathrm{Cdc} 42$ & $\begin{array}{l}\text { plasma membrane; } \\
\text { endomembrane compartments; }\end{array}$ & Regulate membrane ruffling and stress fiber; & {$[191,192]$} \\
\hline RhoD & RhoD/F & $\begin{array}{l}\text { plasma membrane; } \\
\text { endosomes; } \\
\text { the Golgi apparatus; }\end{array}$ & Regulate the formation of filopodia and membrane ruffling; & [193] \\
\hline RhoF & RhoD/F & $\begin{array}{l}\text { nucleoplasm; } \\
\text { the Golgi apparatus; }\end{array}$ & Regulate the formation of filopodia; & [194-197] \\
\hline $\mathrm{RhoH}$ & $\mathrm{RhoH}$ & $\begin{array}{l}\text { plasma membrane; } \\
\text { vesicles; }\end{array}$ & $\begin{array}{l}\text { Regulate lamellipodium extension; } \\
\text { Regulate migratory polarity; }\end{array}$ & {$[198,199]$} \\
\hline Rnd1 & Rnd & $\begin{array}{l}\text { plasma membrane; } \\
\text { vesicles; } \\
\text { cytoplasm; }\end{array}$ & Regulate cell adhesion and cell contraction; & {$[200,201]$} \\
\hline Rnd2 & Rnd & cytoplasm; & Regulate cell contraction; & {$[202,203]$} \\
\hline Rnd3 & Rnd & $\begin{array}{l}\text { plasma membrane; } \\
\text { cytoplasm; }\end{array}$ & Regulate tight junction integrity; & {$[202,204]$} \\
\hline RhoU & Rhou/N & $\begin{array}{l}\text { plasma membrane; } \\
\text { endomembrane compartments; }\end{array}$ & Regulate focal adhesion turnover, filopodia and cell adhesion; & {$[205,206]$} \\
\hline Rhov & Rhou/N & $\begin{array}{l}\text { plasma membrane; } \\
\text { endomembrane compartments; }\end{array}$ & $\begin{array}{l}\text { Regulate filopodia and lamellipodia; regulate the formation of focal } \\
\text { adhesion; }\end{array}$ & {$[146,207,208]$} \\
\hline RhoBTB1 & RhoBTB & Vesicular; & Do not regulate the actin cytoskeleton directly; & {$[146,209,210]$} \\
\hline RhoBTB2 & RhoBTB & Vesicular; & Do not regulate the actin cytoskeleton directly; & {$[146,209,210]$} \\
\hline
\end{tabular}

the cytoskeleton [67]. This hypothesis was confirmed by Stasia et al. who found that microinjection of exonuclease $\mathrm{C} 3$ caused significant changes in the actin filament network of 3T3 cells, including significant inhibition of neutrophil movement and disorder of actin filament assembly, which was explained as the result of ADPribosylation of Rho protein [68]. Morris et al. subsequently used fluorescence in situ hybridization to map the $R H O C$ gene to the $\mathrm{p} 13-\mathrm{p} 21$ band on chromosome 1 [69]. Since then, mounting RhoC-research has focused on its effect on the actin skeleton.

\section{Transcriptional regulation and mutation of RhoC}

Few studies have focused on regulating $\mathrm{RhoC}$ gene expression at the transcriptional level. In one such study, activated p53- when subjected to genotoxic stressdirectly binds to the regulatory element located in the intron 2 region of the RhoC gene, inducing RhoC expression [70]. In addition, ETS Proto-oncogene 1 (Ets-1) transcription factor binds to the promoter and stimulates expression of RhoC during EMT, in colon cancer [71]. In hepatocellular carcinoma (HCC) infected with hepatitis $\mathrm{B}$ virus (HBV), $\mathrm{HBs}$ and $\mathrm{HBx}$ proteins induce 


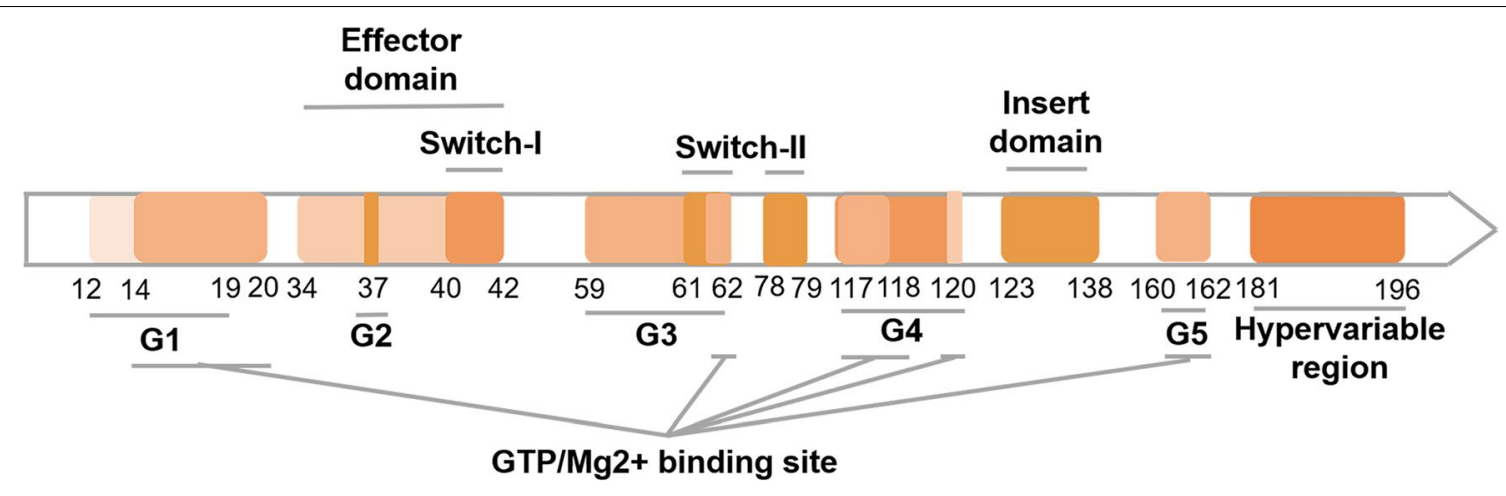

Hypervariable region :

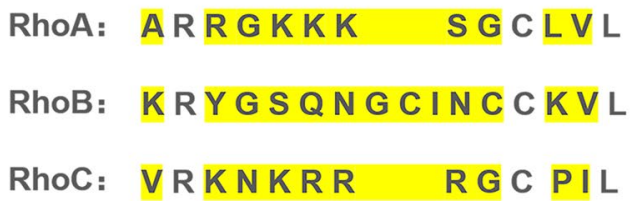

Fig. 1 Rho GTPase domain organization. The sequence comparison of domain structures and hypervariable C-terminal regions of RhoA, RhoB and RhoC is shown. The yellow highlight represents the amino acid differences of RhoA, RhoB and RhoC in the hypervariable region

the expression of Ets-1 transcription factor, thereby enhancing the activity of the RhoC promoter to upregulate RhoC expression [72, 73]. Zhou et al. found that the binding of endogenous HIF- $3 \alpha$ to the RhoC promoter under hypoxia, increases the RhoC mRNA level and promotes cancer cell invasion [51].

MicroRNA (miRNA) regulates gene expression at the post-transcriptional level. Two studies have demonstrated that miR-138 inhibits the migration and invasion of tongue squamous cell carcinoma (TSCC) and head and neck squamous cell carcinoma (HNSCC) cells, respectively, by targeting RhoC mRNA [74, 75]. Liu et al. showed that miR-372 overexpression reduces the expression of RhoC through its three prime untranslated region (3'UTR) and inhibits the proliferation, migration, and invasion of endometrial adenocarcinoma (EC) cells [76]. Many studies have shown that miR-10b inhibits homeobox D10 (HOXD10) in colorectal cancer, metastatic breast cancer, and malignant glioma cells, respectively, resulting in increased expression of $\mathrm{RhoC} \mathrm{[77-80].} \mathrm{In}$ ovarian cancer, miR-519d directly binds to and inhibits the expression of the $3^{\prime} \mathrm{UTR}$ of RhoC mRNA. The negative correlation between miR-519d and RhoC is also demonstrated in a xenotransplantation model in nude mice81. Zhou et al. showed that miR-493 directly targets RhoC, resulting in a significant decrease in its mRNA and protein expression, and inhibits the growth, invasion, and metastasis of gastric cancer cells [82]. In HCC and epithelial ovarian cancer, miR-106b enhances cell migration by inducing RhoC expression $[83,84]$. In a recent study,
miR-302e targets circRhoC-a putative circular RNA (circRNA) emerging from RhoC mRNA-as a tumor suppressor [85]. Xie et al. proved that miR-455 specifically recognizes the $3^{\prime} \mathrm{UTR}$ of $\mathrm{RhoC}$ and inhibits both RhoC expression and the proliferation of hepatoma cells, and promotes cell apoptosis [86]. The latest research shows that the downregulation of miR-17-5p in esophageal cancer cells, leads to the upregulation of RhoC, which is the direct downstream target of miR-17-5p [87]. The role of miRNA in regulating $\mathrm{RhoC}$ expression is indicative of the potential use of this mechanism in developing new cancer treatment schemes. For example, Shao et al. proposed a tumor-triggered personalized miRNA cocktail therapy to treat HCC, by encapsulating miR-199a/b-3p mimics (miR199) and antimiR-10b (antimiR10b) into PCACPthe polymer-based nanoplatform, PEI- $\beta C D @ A d-C D M-$ PEG-and significantly inhibiting cell proliferation and tumor growth [88].

Overexpression of the $\mathrm{RhoC}$ gene is associated with the progression of pancreatic89, liver [90], breast [91], and many other cancers. However, according to current research, RhoC itself does not seem to mutate, but rather promotes cancer metastasis through its overexpression [92]. In a past mutation study, RhoC-43 V (mutated to valine at position 43) is more effective in driving the invasion of ovarian cancer cells, than wild-type RhoC [93]. Another study showed that the dominant negative mutant of RhoC significantly reduces the actin polymerization induced by myosin-interacting guanine nucleotide exchange factor (MyoGEF), and inhibits the polarity and 
invasive activity of breast cancer cells [94]. In addition, when the arginine residue at position 188 of the polybasic region (PBR) of RhoC is replaced with other amino acids, $\mathrm{RhoC}$ membrane localization is significantly inhibited. The consequent RhoC activity is poor, resulting in decreased motility of cancer cells [95].

\section{D migration}

The classical cell migration model (Fig. 2) describes the process of cell migration in terms of four perpetual steps that include 1. Morphological polarization: this includes the formation of lamelli- and filopodia [96]. 2. Formation of new adhesions: in the process of single cell migration, this mainly entails the formation of new cell-matrix adhesions, which is usually driven by actin polymerization and adherence to the ECM through transmembrane receptors $[97,98]$. In the process of collective cell migration, intercellular adhesion helps to coordinate the activities of adjacent cells, resulting in more persistent migratory behavior [99]. 3. Contraction of the cell body: a myosin motor in each moving cell pulls on actin filaments that retract the trailing end of the cell due to the generated contractile forces, moving the cell body forward [100]. 4. Release of trailing adhesions: the adhesion between the trailing end of the cell and the surrounding matrix is dissociated, whereby the cell moves forward [101].

\section{Morphological polarization}

The first step in cell migration is the formation of projections-mainly lamelli- and filopodia-from the leading edge of the cell, the location of which determines the direction of migration [96, 102]. RhoC can regulate the formation of protrusions in many cells, and its expression and regulation has been proven in human macrophages, as well as prostate cancer, colorectal carcinoma, and breast cancer cells, respectively [103, 104]. During cell migration, myosin II activity inhibits the formation of frontal protrusions [105]. However, RhoC plays a role in limiting myosin II activity, allowing cells to form the projections required for migration $[105,106]$. RhoC expression and activation are further required for directional migration and invasion, as it seems to be effective in limiting lamellipodial broadening [60, 107]. When RhoC is depleted, cells will form abnormally wide lamellipodia with multiple branches due to defective actin polymerization in the leading edge of cells. These branches cannot effectively penetrate the ECM, resulting in reduced migration rate and persistence [108, 109]. Gou et al. proved that ectopic RhoC overexpression can enhance the formation of lamellipodia in ovarian carcinoma cells [110]. Another study used MTLn3 cells-a highly metastatic rat mammary adenocarcinoma cell line-to demonstrate that p190RhoGEF and p190RhoGAP act as upstream regulators that limit RhoC activation in specific regions, influencing the formation of specific functional protrusions, in the regulation of migration-related processes [111]. Coincidentally, PSD95/Discs-large/ZO-1 homology (PDZ)-RhoGEF is also involved in RhoC activation in ovarian carcinoma [112, 113]. Moreover, Willmer et al. proved that heat shock proteins 90 and $70(\mathrm{Hsp} 90 / \mathrm{Hsp} 70)$ organizing protein (Hop) is another upstream molecule affecting RhoC, and it is co-localized with actin in lamellipodia. Knockdown

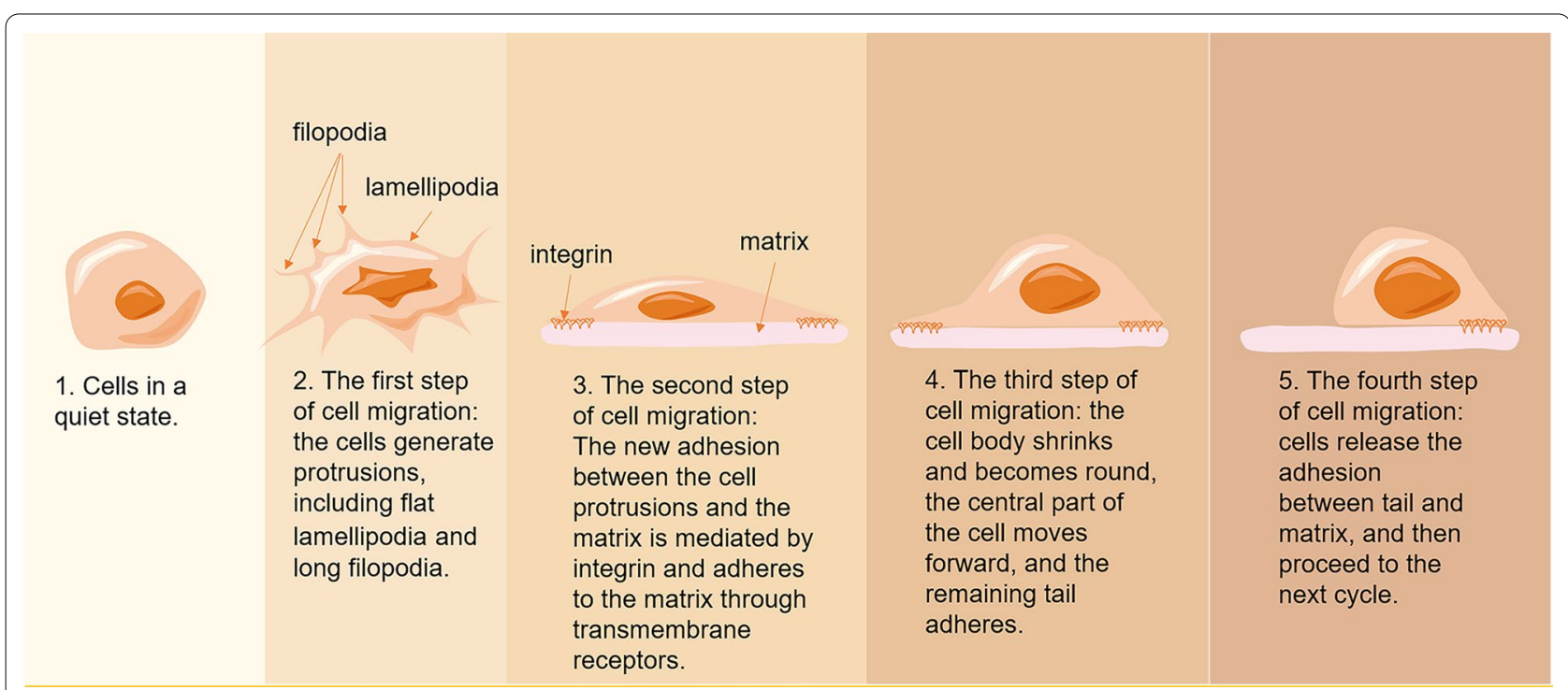

Fig. 2 Four-step cycle of cell migration 
of Hop results in decreased RhoC levels in breast cancer cells, notably inhibiting the formation of filopodia [114]. Traditionally, RhoC is thought to regulate the migration phenotype through the Rho-associated protein kinases (ROCK) 1 and 2. However, Vega et al. found that neither ROCK1- nor ROCK2-depletion phenotypes resemble the RhoC-inhibition phenotype, inferring that $\mathrm{RhoC}$, at least partially, does not regulate cell morphology through ROCK1 or ROCK2. Furthermore, although ROCK2 and RhoC-knockdown both reduce directional migration, they seem to work by different mechanisms: RhoC-knockout cells have broad lamellipodia, while ROCK2-knockout cells have narrow protuberances [108]. Moreover, Formin-like protein 3 (FMNL3) reportedly interacts directly with $\mathrm{RhoC}$ in vivo and in vitro, is co-localized in the cytoplasm, activates the downstream signal transduction of FAK/MAPK/Akt, and limits the widening of the lamellar membrane to promote cell polarization and migration [104]. In addition, Vega et al. identified FMNL3 as a new RhoC-specific target, and showed that $\mathrm{RhoC}$ promotes polarized migration in $\mathrm{PC} 3$ prostate cancer and MDA-MB-231 breast cancer cells, respectively, through FMNL3. Expression of FMNL3 rescues the broad lamellipodial phenotype induced by RhoC knockdown [108]. Inactivation of cofilin-a protein that promotes actin polymerization-is an important step in its activity cycle. RhoC activation can trigger the ROCK/ Lin11/Isl1/Mec3 kinase (LIMK) pathway to phosphorylate and inactivate cofilin, thereby regulating the actin cytoskeleton to regulate human glioma, squamous cell carcinoma, and breast cancer cell migration [114-118]. EMT is also closely related to the migration of cancer cells. Sequeira et al. illustrated that RhoC inactivation induces morphological changes commensurate with EMT, accompanied by increased random motility and decreased directional migration, in PC3 prostate cancer cells [119]. In cervical cancer cells, Notch homolog 1, translocation-associated (Drosophila) (Notch1) and RhoC make similar phenotypic contributions to EMT, and Notch1 inhibition can reduce RhoC activity, suggesting that the latter plays a role as an effector of the former [110]. These processes are summarized in Fig. 3.

The role of $\mathrm{RhoC}$ in limiting lamellipodia broadening is clear. Although more than one specific regulatory pathway has been found, they have not been clearly studied. Also, the mechanism may not be limited to the above regulatory methods, and the molecules or pathways interacting with $\mathrm{RhoC}$ have not been fully scrutinized.

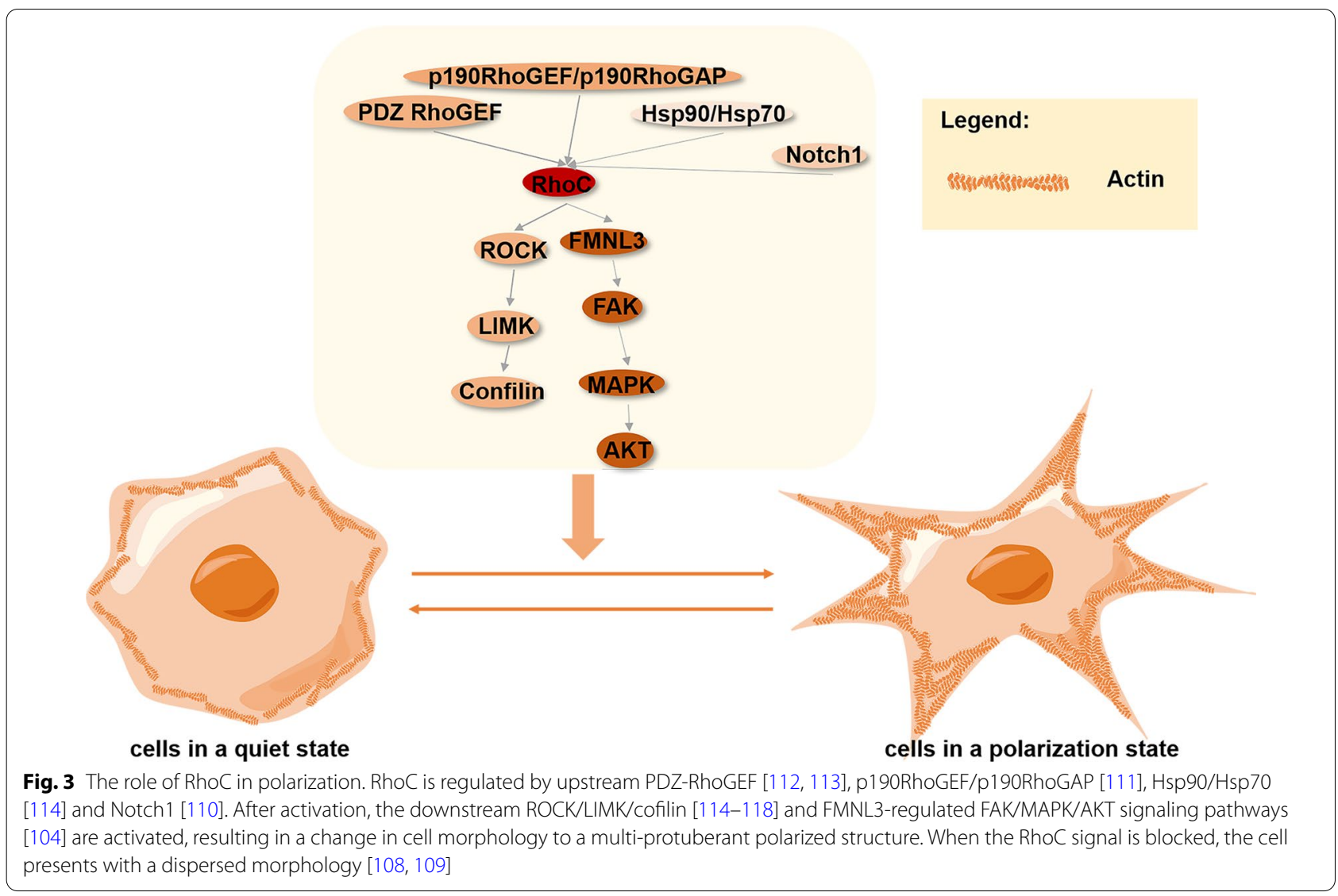


For example, IQ motif-containing GTPase-activating protein 1 (IQGAP1) is also associated with cell migration $[120,121]$, and has been proven to be an effector of RhoC in promoting the migration of breast cancer [122] and gastric cancer cells[44] respectively; it is also observed at the leading edge of migrating cells [122]. Coincidentally, $\mathrm{RhoC}$ is also enriched in the leading edge of migrating cells [123]. We have reason to believe that RhoC can regulate protrusion formation through IQGAP1, but strong experimental proof is lacking, as many similar molecules' functions have not been specified. Future research should pay more attention to this matter.

\section{Regulation of cell adhesion}

Effective cell migration requires precise regulation of cell adhesion, including cell-matrix adhesion and cell-cell adhesion.

In the process of single cell migration, cells need to continually form new adhesions between the cellular projections and the matrix, to anchor the cells; this is called cell-matrix adhesion [124]. To enable cell movement, the formation and dissociation of cell-matrix adhesions needs to be repeatedly cycled [125]. At the leading edge of a cell, lamellipodia form an adhesive force that connects the ECM to the actin skeleton, thereby anchoring the protrusion [126]. Actin stress fibers in the projections connect the cells to the matrix, thus providing traction for leading edge advancement and whole cell body displacement [106]. In a study of inflammatory and aggressive breast cancers, the role of RhoC in regulating cell-matrix adhesion is particularly important, as the response to matrix adhesion signals transmitted by integrin-by promoting the assembly of adhesion spots and stress fibers-is a key function of the Rho protein [127]. Bravo-Cordero et al. observed in MTLn3 cells, that RhoC activity is enriched in the area behind the front edge of a cell, and proved that RhoC activation increases the cofilin level in a ROCK-dependent manner, thereby promoting the formation of cellular protrusions in the migratory direction. The spatial localization of RhoC activity can be used as a directional compass to limit the polymerization position of actin by limiting the activity of cofilin, to determine where the protrusion should form [123]. To determine which molecules are related to signal conduction downstream of RhoC during the regulation of matrix adhesion, microarray analysis was conducted on MCF10A breast epithelial cells in which RhoC had been overexpressed. It was found that RhoC-overexpression significantly increased the mRNA level of fibronectin and Caveolin-2, as well as the migration ability of the cells [128]. Moreover, Caveolin-1 interacts with RhoC in pancreatic cancer, bladder cancer, and inflammatory breast cancer cells, respectively129-131. Furthermore, in migrating pancreatic carcinoma cells, the RhoC C-terminus domain co-localizes with, as well as enhances the activation and circulation of integrin $\alpha 5 \beta 1$, in addition to reducing cell adhesion and promoting cell migration. Src in melanoma cells is also involved in processes that occur downstream of RhoC engagement with integrin $\alpha 5 \beta 1$ $[132,133]$. Low expression of NADPH oxidase 4 (NOX4) is related to decreased cell-matrix and cell-cell adhesions. Crosas-Molist et al. described for the first time that low expression of NOX4 leads to high expression of RhoC in HCC, which weakens the adhesion between cells and ECM, resulting in increased cell migration and invasion [134]. The Rho-specific GEF, Tumor endothelial marker 4 (TEM4), is an important regulator of the actin cytoskeleton that modulates cell-matrix adhesion by signaling to RhoC. The depletion of TEM4 and RhoC leads to increased cell-matrix adhesion and decreased cell migration in endothelial cell, which is also affected by ROCK [106].During migration, matrix adhesion is not only weakened, but also a dynamic cycle of formation and dissociation. By constantly updating the adhesion sites, the cells move forward. The regulation of RhoC on integrin is in line with this process. The current literature only shows the inhibitory effect of NOX4 on RhoC, but whether there is another link between NOX4 and RhoC remains to be determined.

Cell-cell adhesion is mediated by four main types of junctions, namely adherens, tight and gap junctions, and desmosomes [7]. Dependent on the different cell types and tissue environment, cells retain intercellular adhesion when they migrate collectively, which enables the cells to interact with each other and alter cell polarity. The process of single-cell migration requires the loss or weakening of intercellular adhesion [135]. Studies have shown that cells inhibited by RhoC showed a tight junction tissue structure, indicating that RhoC regulates both cell-matrix and cell-cell adhesion, in the migration cascade [127]. RhoC mainly regulates two junctional complexes, namely tight (TJs) and adherens junctions ( $\mathrm{AJs})$-constituting the endothelial barrier-between cells. In one study, it was found that RhoC is localized and activated at the endothelial junction in primary human endothelial cells, resulting in the destruction of intercellular junctions [136]. AJs connect the actin cytoskeletons of adjacent cells and depend on the homogenous binding of cadherins, including E- and $\mathrm{N}$-cadherin. The expression and localization of E-cadherin are deranged by activated RhoC in prostate cancer cell [137]. Similarly, RhoC and ROCK mediate the breakdown of TJs and AJs in endothelial cells [59]. Rho GTPase activating protein 18 (ARHGAP18) is a type of RhoGAP that specifically acts on RhoC; its knockdown leads to RhoC-overexpression, which directly leads to 
the destruction of ROCK-dependent AJs in fibroblasts and human umbilical vein endothelial cells (HUVEC) [59, 138, 139]. Studies have shown that RhoC and Mammalian Diaphanous 1 (mDia1) are co-localized in migrating cells, and depletion of the latter results in a phenotype similar to what is seen in RhoC depletion. RhoC-overexpressing cells can rapidly break and recombine AJs, resulting in highly dynamic cell behavior. Downstream of RhoC, both mDial and ROCK are involved in the regulation of AJs [140]. RhoC maintains AJ stability through mDial and antagonizes the destabilization of ROCK-mediated intercellular adhesion destruction, which is consistent with the synergistic effect of the two pathways necessary for RhoC signaling [140-142]. Figure 4 provides a graphical summary of these data.

The dynamic regulation of cell adhesion ability is essential to the stability of migration cycle. In this process, RhoC mediates the destruction of tight connection and adhesion connection through different mechanisms. The most important is the role of ROCK and mDia1, which are controlled by each other and play the opposite role.

Cell-cell adhesion: tight junctions and adherens junctions are involved in cell migration [59]. ARHGAP1859,138,139 regulates the activities of RhoC and downstream ROCK [59], N-cadherin [137], and mDia1 [140], resulting in the dynamic behavior of cells.

\section{Contraction of the cell body}

In the process of migration, cells can produce an active pulling force through contraction of actin and myosin, to make cells move forward [143]. The contractile apparatus in cells consists of F-actin and myosin II. Phosphorylated myosin light chain (MLC) promotes the contraction of myosin, facilitating its interaction with $\mathrm{F}$-actin to produce a contractile force. In a migrating cell, contractile force is usually applied to focal adhesions to destroy the adherence and cause cell contraction [100]. The key factor of assembly and contraction of actin and myosin is the activation of myosin II by MLC phosphorylation, mediated by ROCK [144]. Moreover, ROCK indirectly increases myosin II activity by inhibiting MLC phosphatase (MLCP) [145]. Although ROCK can be simultaneously activated by RhoA and RhoC, research by Jackson et al. has shown that RhoA is not required for the formation of actin stress fibers, the assembly of which can be induced by both active RhoA and RhoC $[145,146]$. Durkin et al. found that the ROCK signal mediated by RhoC can be expressed independent of the RhoA signal in both HeLa and human osteosarcoma (U-2 OS) cells, to

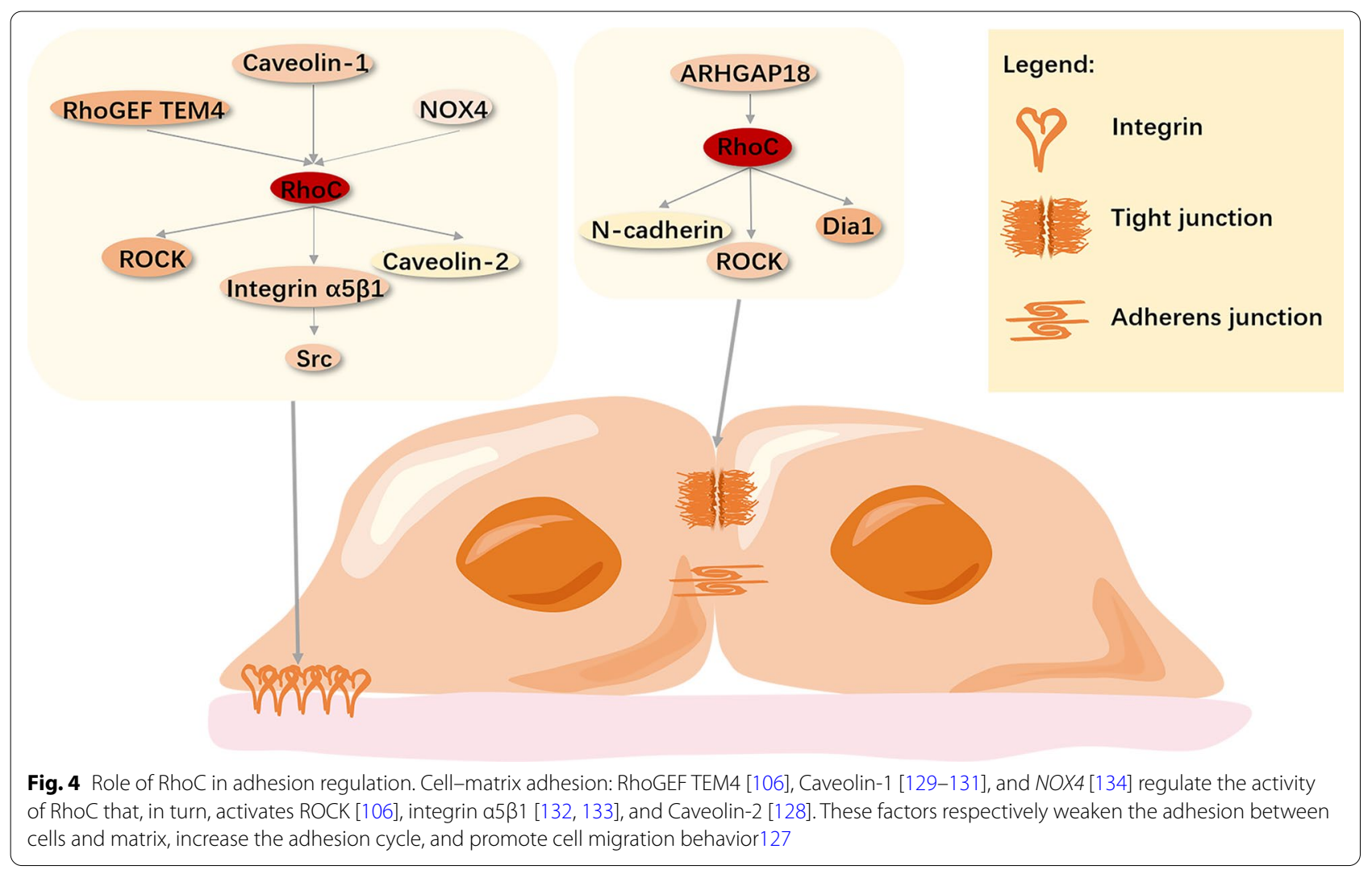


drive the redistribution of myosin II. This promotes the contraction of cells, which can be suppressed by RhoD/ PAK6 signaling [147]. However, the contraction due to increased ROCK-signaling cannot fully account for the activation of RhoC, which indicates that other effector proteins need to cooperate with ROCK [148]. In HeLa, U-2 OS, and human ovarian clear cell carcinoma (ES-2) cells, MLK-related kinase (MRK) also acts as an effector of RhoC and dynamically regulates myosin by controlling MLCP activity during cell migration [149, 150]. TEM4, which was discussed previously, not only regulates cellmatrix adhesion through RhoC, but also limits myosin II activity to control cell contraction [106]. The interactions responsible for cell contraction, are displayed in Fig. 5.

\section{Tail retraction}

To conclude the forward movement of the cell, it is necessary to extend the protrusion and retract the tail [138]. The migration cycle culminates in the release of posterior adhesions followed by tail retraction - that requires Rho kinase and is a myosin-dependent process97-resulting in a forward displacement of the cell body [151]. In some cells, the rate of backward release determines the overall migration rate. RhoA-mediated ROCK activation has been suggested to play an important role in this process[152] and it has been shown that ROCK1-depleted cells present with defective tail retraction, which is consistent with the phenotype of RhoA-knockout cells [151, 153]. RhoB-deletion appears not to affect tail length [154]. As mentioned, RhoC-deficient cells do not have long tails and show a diffuse phenotype. Therefore, current research outcomes seemingly indicate that RhoC does not control the post-release process of the migration cycle.

\section{D migration}

In 2D cell culture, cells have larger lamelli- and filopodia, whereas 3D cells have a less exaggerated appearance [155]. Cell migration in a 3D environment is closely related to the process of cancer metastasis, as cancer cells can use the 3D migration mode to invade their environment [156]. In a 3D environment, most cells move by three modes, namely amoeboid, lobopodial and mesenchymal (called lamellipodial) migration [157]. Three important factors regulating 3D cell migration patterns are cell-matrix adhesion, the Rho family of

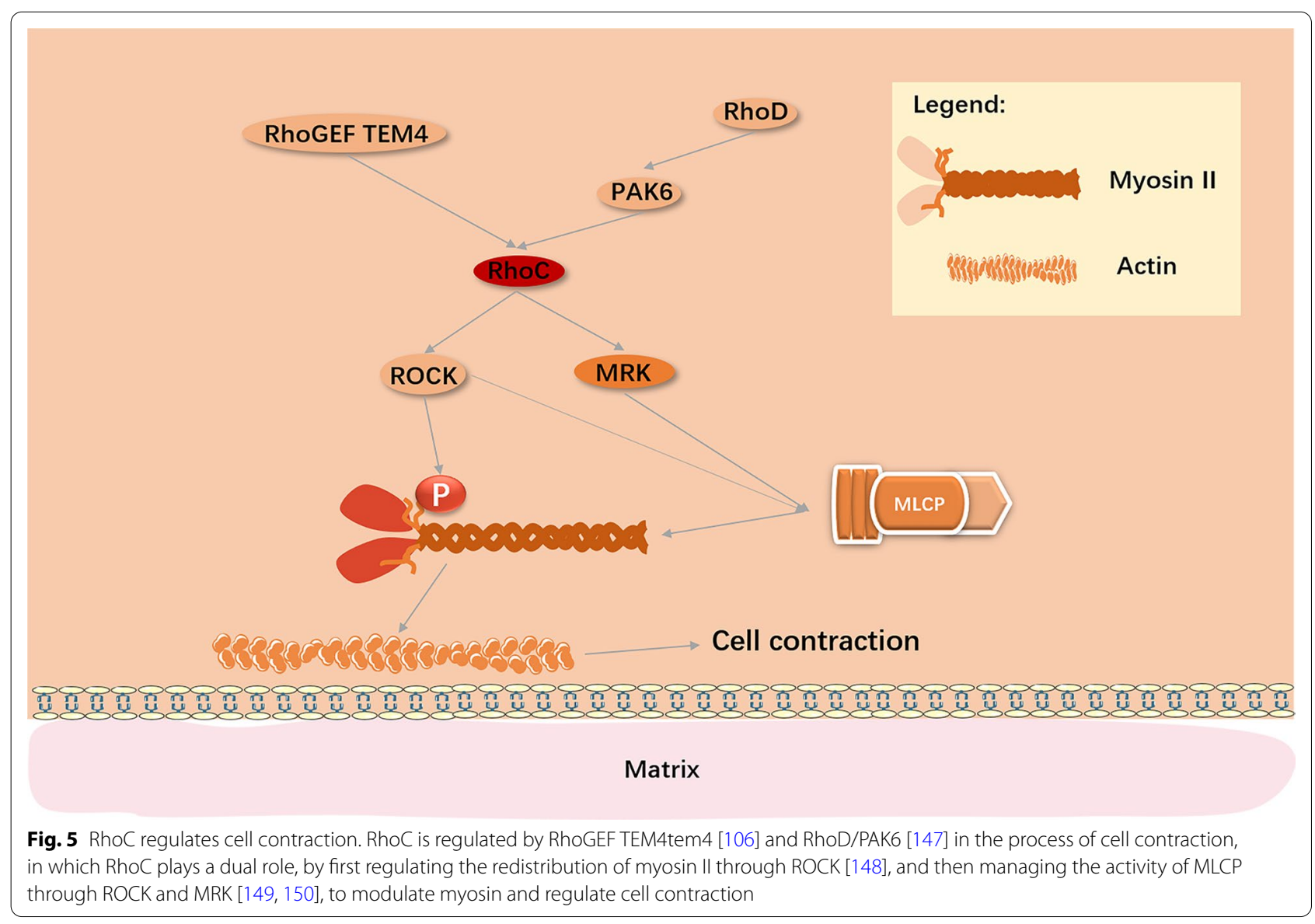


small GTPases, and protease [7]. Studies in 3D environments show that cancer cells switch between these invasion patterns according to the activation of specific Rho GTPases, during the process of metastasis [158, 159], as seen in Fig. 6.

\section{Amoeboid migration}

Amoeboid cell migration is similar to the movement of protozoal amoebae, which is characterized by round cells undergoing extensive deformation, and low-level adhesion. The migration strategies include contractionbased blebbing or entirely polymerization-driven gliding [163]. This form of vesicular migration-morphologically featured as movement facilitated by the formation of vesicles-is particularly useful for cell motility in a confined space. Activated myosin II increases local hydrostatic pressure, resulting in localized rupture of the actin cytoskeleton from the membrane. Resultantly, the membrane is rapidly pushed outward by cytoplasmic fluid flow, which promotes the formation of vesicles. Thereafter, actin polymerizes on the membrane to form a new actin cortex, promoting vesicle contraction [156]. High-resolution imaging demonstrated that RhoC-overexpressing cancer cells invade tissues by extending small membrane protrusions and vesicles-a typical amoeboid migration pattern-in a zebrafish xenotransplantation model164. High expression of RhoC in HCC cells significantly increases myosin II activity and the percentage of vesicles, whereas high myosin II activity and low adhesion are key to rapid amoeboid migration [165]. Lehman et al. demonstrated that RhoC-depletion reduces cell invasion in a lymphatic system invasion model used to study amoeboid movement in cancer metastasis [166]. ROCK-a classic effector of Rho GTPases-also plays a role in the regulation of amoeboid migration, and its affinity for RhoC is greater than for RhoA [115]. Kitzing et al. found that FMNL2 selectively interacts with RhoC and as an effector thereof, to regulate RhoC-dependent amoeboid migration. The expression of RhoC can partially alleviate the self-inhibition of FMNL2, indicating that activated RhoC regulates FMNL2 regulated actin dynamics [158]. The loss of NOX4 can up-regulate RhoC expression and actin contractility, thereby promoting amoeboid migration [164].

\section{Lobopodial migration}

Lobopodial migration can be regarded as a combination of amoeboid and mesenchymal migration. When cells migrate in limited 3D matrix, they switch to lobopodial migration [167], where they are elongated and

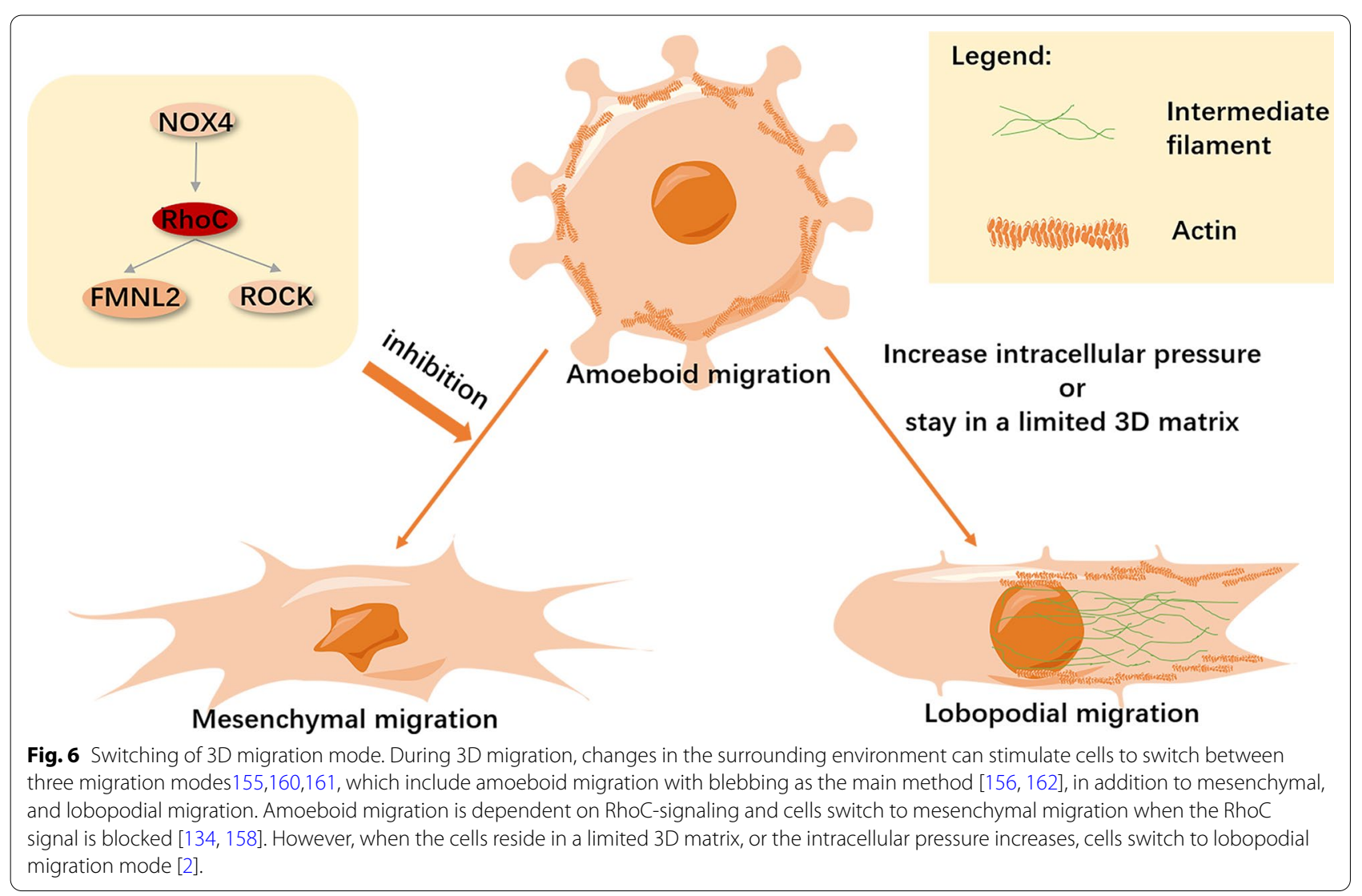


the cell membrane clings to the nucleus, dividing the cell into two parts [168]. Myosin II arcs, which are connected to vimentin intermediate filaments, produce tension that causes the nucleus to move forward in a piston-like manner, resulting in a pressure difference between the front and back ends of the cell. Resultantly, the front end produces lobopodial protrusions, forming new cell-matrix adhesions that circulate and cause the cell to move forward [169]. Research has shown that Rho, ROCK and myosin II constitute part of the lobopodial migration mechanism. The inhibitory effects of Rho and ROCK can switch lobopodial migration to lamellipodia-based 3D migration [170]. It has been observed in acute lymphoblastic leukemia cells that increasing intracellular pressure can also induce a change from low-pressure lamellipodial to high-pressure lobopodial migration [161], and increased intracellular pressure can be achieved by increasing the contractility of myosin in human foreskin fibroblasts (HFFs) [171]. Although current research does not indicate whether RhoC plays a role in regulating lobopodial migration, there is clear evidence that the RhoC-mediated ROCK signal can be induced independent of the myosin II-regulated RhoA signal $[105,106]$. Therefore, it is reasonable to infer that RhoC also plays an indispensable role in regulating lobopodial migration, but there is a lack of relevant research to prove this.

\section{Mesenchymal migration}

The mesenchymal migration pattern is largely similar to that of 2D migration, in which the leading edge of a cell undergoes actin polymerization to produce lamelli- and filopodia [2]. The mesenchymal migration pattern is characterized by slender, spindle-shaped cells, and extracellular proteolysis. Notably, it has been observed in HT-1080 fibrosarcoma and MDA-MB-231 breast carcinoma cells, respectively, that the inhibition of pericellular proteolysis gives rise to a migration mode switch from mesenchymal to amoeboid movement [172]. Additionally, Rho GTPases must be inhibited during mesenchymal migration, as active Rho will cause cells to change into a Rhodependent amoeba-like migration mode [173]. Although the literature does not explain the role of RhoC in mesenchymal migration, we believe that it is indispensable in the regulation of this process.

\section{Conclusion}

Migration plays an important role in the occurrence and development of many physiological and pathological processes. The regulation of migration is a complex process involving many molecules and a wide range of mechanisms. In depth understanding of migration can help us tackle cancer metastasis, embryonic development, and immune response. In this paper, we reviewed the role of RhoC-a classic member of the Rho family-in both typical 2D, and newly proposed 3D migration models. Since its discovery, it has been difficult to develop unique, RhoC-specific small molecule inhibitors or activators, due to the high level of homology between RhoA, RhoB, and $\mathrm{RhoC}$ as well as the emergence of $\mathrm{RhoC}$ as the whole Rho subfamily. Later technologies, such as siRNA, enabled researchers to discover the unique effects of RhoC that were independent of RhoA and RhoB. In recent years, with increased understanding of cell migration mechanisms, the major impact of RhoC on cell motility has become evident. In the classic $2 \mathrm{D}$ cell migration cycle, all processes, except for tail retraction, are precisely regulated by RhoC. In the emerging 3D migration theory, amoeboid migration is also known as the Rho-dependent migration model, in which the important RhoA-independent role of $\mathrm{RhoC}$ has been proven. Studying RhoC functionality can contribute to a better understanding of cancer metastasis, as well as aid in development of new anti-metastasis therapeutic targets. Cancer metastasis has been a major challenge for the past century, the solution to which requires deeper and wider understanding of its internal mechanism. The significant role of RhoC in tumor metastasis suggests that it may have great potential as a target for anti-metastasis therapy. At present, anticancer research involving $\mathrm{RhoC}$ is not very extensive, possibly due to insufficient availability of detail concerning the mechanism of RhoC action in cancer metastasis. However, existing studies clearly indicate that both drugs and vaccines against $\mathrm{RhoC}$ have achieved excellent results. Perhaps RhoC-targeted treatment schemes will be accepted into clinical practice in future. Further to the pathological process, RhoC-controlled amoeboid migration is also of great significance in many physiological processes. The functions of RhoC are very diverse, but due to the limitations of current technology and the development of specific inhibitors, our understanding of RhoC is still limited, and it is difficult to accurately locate RhoC in related studies, which limits the independent exploration of RhoC. In addition, research on 3D migration is more complex than $2 \mathrm{D}$ migration, with a lack of convenient and controllable detection methods, thereby hindering research progress. The mechanisms of RhoC, such as how RhoC plays a role in lobopodial migration and mesenchymal migration, remain unclear and warrant further investigation.

\section{Abbreviations}

2D: Two-dimensional; 3D: Three-dimensional; 3’UTR: Three prime untranslated region; AJ: Adherens junction; ARHGAP18: Rho GTPase activating protein 18; EMT: Epithelial-mesenchymal transition; ERK: Extracellular signal-regulated kinase; Ets-1: ETS Proto-oncogene 1; FAK: Focal adhesion kinase; FMNL3: Formin-like protein 3; GAP: GTPase activating protein; GEF: Guanine nucleotide 
exchange factor; Hop: Hsp90/Hsp70 organizing protein; Hsp: Heat shock protein; HUVEC: Human umbilical vein endothelial cells; IQGAP1: IQ motifcontaining GTPase-activating protein 1; LIMK: Lin11/IsI1/Mec3 kinase; mDia1: Mammalian Diaphanous-related formin 1; MLC: Myosin light chain; MLCP: MLC phosphatase; MRK: MLK-related kinase; NADPH: Nicotinamide adenine dinucleotide phosphate; Notch1: Notch homolog 1, translocation-associated (Drosophila); NOX4: NADPH oxidase 4; PBR: Polybasic region; PCACP: PEI-BCD@ Ad-CDM-PEG; PDZ: PSD-95/Discs-large/ZO-1 homology; PI3K: Phosphoinositide 3-kinase; PKC: Protein kinase C; PTEN: Phosphatase and tensin homolog; ROCK: Rho-associated protein kinase; TEM4: Tumor endothelial marker 4; TJ: Tight junction; WASP: Wiskott-Aldrich syndrome protein; WAVE: WASP-family verprolin-homologous protein.

\section{Acknowledgements}

We would like to thank Editage (www.editage.cn) for English language editing.

\section{Authors' contributions}

$Y L$ contributed to the design of the study and wrote the first draft of the manuscript. YJ, ZL and BL drew the pictures. TL and DZ contributed to the editing of the manuscript. All authors read and approved the final manuscript.

\section{Funding}

This study was supported by the Chinese Academy of Medical Sciences (CAMS) Innovation Fund for Medical Sciences [Grant Numbers CAMS-2017-I2M-1-007].

\section{Availability of data and materials}

Not applicable.

\section{Declarations}

Ethics approval and consent to participate

Not applicable.

\section{Consent for publication}

Not applicable.

\section{Competing interests}

The authors declare that they have no competing interests.

\section{Author details}

${ }^{1}$ Department of Plastic and Reconstructive Surgery, The First Hospital of Jilin University, Changchun, Jilin, China. ${ }^{2}$ Department of Neurology and Neuroscience Center, The First Hospital of Jilin University, Changchun, China.

\section{Received: 23 July 2021 Accepted: 27 September 2021}

\section{Published online: 09 October 2021}

\section{References}

1. Paluch EK, Aspalter IM, Sixt M. Focal adhesion-independent cell migration. Annu Rev Cell Dev Biol. 2016;32:469-90.

2. Yamada KM, Sixt M. Mechanisms of $3 D$ cell migration. Nat Rev Mol Cell Biol. 2019;20(12):738-52.

3. Baker BM, Chen CS. Deconstructing the third dimension: how 3D culture microenvironments alter cellular cues. J Cell Sci. 2012;125(Pt 13):3015-24.

4. Grada A, Otero-Vinas M, Prieto-Castrillo F, Obagi Z, Falanga V. Research techniques made simple: analysis of collective cell migration using the wound healing assay. J Investig Dermatol. 2017;137(2):e11-6.

5. Lauffenburger DA, Horwitz AF. Cell migration: a physically integrated molecular process. Cell. 1996;84(3):359-69.

6. Alberts B, Johnson A, Lewis J, Raff M, Roberts K, Walter P. Molecular biology of the cell, vol 230; 2007.

7. Trepat X, Chen Z, Jacobson K. Cell migration. Compr Physiol. 2012;2(4):2369-92.

8. Friedl P, Gilmour D. Collective cell migration in morphogenesis, regeneration and cancer. Nat Rev Mol Cell Biol. 2009;10(7):445-57.
9. Lintz M, Muñoz A, Reinhart-King CA. The mechanics of single cell and collective migration of tumor cells. J Biomech Eng. 2017;139(2):0210051-9.

10. Ridley AJ. Rho GTPase signalling in cell migration. Curr Opin Cell Biol. 2015;36:103-12

11. Haga RB, Ridley AJ. Rho GTPases: regulation and roles in cancer cell biology. Small GTPases. 2016;7(4):207-21.

12. Warner H, Wilson BJ, Caswell PT. Control of adhesion and protrusion in cell migration by Rho GTPases. Curr Opin Cell Biol. 2019;56:64-70.

13. Mann KM, Ying H, Juan J, Jenkins NA, Copeland NG. KRAS-related proteins in pancreatic cancer. Pharmacol Ther. 2016;168:29-42.

14. Santarpia L, Lippman SM, El-Naggar AK. Targeting the MAPK-RASRAF signaling pathway in cancer therapy. Expert Opin Ther Targets. 2012;16(1):103-19.

15. Rottner K, Stradal TEB, Chen B. WAVE regulatory complex. Curr Biol CB. 2021;31(10):R512-r517.

16. Frugtniet $B$, Jiang WG, Martin TA. Role of the WASP and WAVE family proteins in breast cancer invasion and metastasis. Breast Cancer (Dove Medical Press). 2015;7:99-109.

17. Sossey-Alaoui K, Li X, Ranalli TA, Cowell JK. WAVE3-mediated cell migration and lamellipodia formation are regulated downstream of phosphatidylinositol 3-kinase. J Biol Chem. 2005;280(23):21748-55.

18. Lu J, Wang SL, Wang YC, WU YN, Yu X, Zhao WZ, Wang JH. High WAVE3 expression correlates with proliferation, migration and invasion in human ovarian cancer. Oncotarget. 2017;8(25):41189-201.

19. Takahashi K, Suzuki K. WAVE2, N-WASP, and Mena facilitate cell invasion via phosphatidylinositol 3-kinase-dependent local accumulation of actin filaments. J Cell Biochem. 2011;112(11):3421-9.

20. Wang Y, Liu H, Bian Y, An J, Duan X, Wan J, Yao X, Du C, Ni C, Zhu L, et al. Low SCRIB expression in fibroblasts promotes invasion of lung cancer cells. Life Sci. 2020:256:117955.

21. Nola S, Sebbagh M, Marchetto S, Osmani N, Nourry C, Audebert S, Navarro C, Rachel R, Montcouquiol M, Sans N, et al. Scrib regulates PAK activity during the cell migration process. Hum Mol Genet. 2008;17(22):3552-65.

22. Anastas JN, Biechele TL, Robitaille M, Muster J, Allison KH, Angers S, Moon RT. A protein complex of SCRIB, NOS1AP and VANGL1 regulates cell polarity and migration, and is associated with breast cancer progression. Oncogene. 2012;31(32):3696-708.

23. Baker L, BeGora M, Au Yeung F, Feigin ME, Rosenberg AZ, Lowe SW, Kislinger T, Muthuswamy SK. Scribble is required for pregnancyinduced alveologenesis in the adult mammary gland. J Cell Sci. 2016;129(12):2307-15.

24. Aranda V, Nolan ME, Muthuswamy SK. Par complex in cancer: a regulator of normal cell polarity joins the dark side. Oncogene. 2008;27(55):6878-87.

25. Tuccilli C, Baldini E, Arlot-Bonnemains Y, Chesnel F, Sorrenti S, De Vito C, D'Armiento E, Antonelli A, Fallahi P, Watutantrige S, et al. Expression and prognostic value of the cell polarity PAR complex members in thyroid cancer. Int J Oncol. 2017;50(4):1413-22.

26. Verret B, Cortes J, Bachelot T, Andre F, Arnedos M. Efficacy of PI3K inhibitors in advanced breast cancer. Ann Oncol. 2019;30(Suppl_10):X12-20.

27. Lee YR, Chen M, Pandolfi PP. The functions and regulation of the PTEN tumour suppressor: new modes and prospects. Nat Rev Mol Cell Biol. 2018;19(9):547-62.

28. Zeng Q, Zhu Z, Song L, He Z. Transferred by exosomes-derived MiR19b-3p targets PTEN to regulate esophageal cancer cell apoptosis, migration and invasion. 2020. Biosci Rep. https://doi.org/10.1042/ BSR20201858.

29. BommaReddy RR, Patel R, Smalley T, Acevedo-Duncan M. Effects of atypical protein kinase $C$ inhibitor (DNDA) on lung cancer proliferation and migration by PKC-1/FAK ubiquitination through the CbI-b pathway. Onco Targets Ther. 2020;13:1661-76.

30. Wu HJ, Hao M, Yeo SK, Guan JL. FAK signaling in cancer-associated fibroblasts promotes breast cancer cell migration and metastasis by exosomal miRNAs-mediated intercellular communication. Oncogene. 2020;39(12):2539-49.

31. Zhao X, Guan JL. Focal adhesion kinase and its signaling pathways in cell migration and angiogenesis. Adv Drug Deliv Rev. 2011;63(8):610-5. 
32. Li J, Guo Y, Duan L, Hu X, Zhang X, Hu J, Huang L, He R, Hu Z, Luo W, et al. AKR1B10 promotes breast cancer cell migration and invasion via activation of ERK signaling. Oncotarget. 2017;8(20):33694-703.

33. Roskoski R Jr. Src protein-tyrosine kinase structure, mechanism, and small molecule inhibitors. Pharmacol Res. 2015;94:9-25.

34. Zhao L, Li X, Song N, Li A, Hou K, Qu X, Che X, Liu Y. Src promotes EGFinduced epithelial-to-mesenchymal transition and migration in gastric cancer cells by upregulating ZEB1 and ZEB2 through AKT. Cell Biol Int. 2018;42(3):294-302

35. Thomas P, Pranatharthi A, Ross C, Srivastava S. RhoC: a fascinating journey from a cytoskeletal organizer to a Cancer stem cell therapeutic target. J Exp Clin Cancer Res CR. 2019;38(1):328.

36. Guo Y, Wang J, Zhou K, LV J, Wang L, Gao S, Keller ET, Zhang ZS, Wang Q, Yao Z. Cytotoxic necrotizing factor 1 promotes bladder cancer angiogenesis through activating RhoC. FASEB J. 2020;34(6):7927-40.

37. Shi D, Wu F, Mu S, Hu B, Zhong B, Gao F, Qing X, Liu J, Zhang Z, Shao Z. LnCRNA AFAP1-AS1 promotes tumorigenesis and epithelial-mesenchymal transition of osteosarcoma through RhoC/ROCK1/p38MAPK/Twist1 signaling pathway. J Exp Clin Cancer Res CR. 2019;38(1):375.

38. Pranatharthi A, Thomas P, Udayashankar AH, Bhavani C, Suresh SB, Krishna S, Thatte J, Srikantia N, Ross CR, Srivastava S. RhoC regulates radioresistance via crosstalk of ROCK2 with the DNA repair machinery in cervical cancer. J Exp Clin Cancer Res CR. 2019;38(1):392.

39. Bueno De Paiva L, Aline Bernusso V, Machado-Neto JA, Traina F, Ridley AJ, Olalla-Saad ST, Lazarini M. Effects of RhoA and RhoC upon the sensitivity of prostate cancer cells to glutamine deprivation. Small GTPases. 2021:12(1):20-6.

40. Rosenthal DT, Zhang J, Bao L, Zhu L, Wu Z, Toy K, Kleer CG, Merajver SD. RhoC impacts the metastatic potential and abundance of breast cancer stem cells. PLoS ONE. 2012;7(7):e40979.

41. Yuan Z, Su J, You JF, Wang JL, Cui XL, Zheng J. Correlation of expression of RhoC with invasiveness of breast cancer cells in vitro. Zhonghua zhong liu za zhi Chin J Oncol. 2007:29(12):898-903.

42. Xu XD, Shen HB, Zhu L, Lu JQ, Zhang L, Luo ZY, Wu YQ. Anti-RhoC siRNAs inhibit the proliferation and invasiveness of breast cancer cells via modulating the KAl1, MMP9, and CXCR4 expression. Onco Targets Ther. 2017;10:1827-34.

43. Wu Y, Chen YC, Sang JR, Xu WR. RhoC protein stimulates migration of gastric cancer cells through interaction with scaffold protein IQGAP1. Mol Med Rep. 2011;4(4):697-703.

44. Liu N, Zhang G, Bi F, Pan Y, Xue Y, Shi Y, Yao L, Zhao L, Zheng Y, Fan D. RhoC is essential for the metastasis of gastric cancer. J Mol Med (Berl). 2007:85(10):1149-56.

45. Ha YJ, Tak KH, Kim SK, Kim CW, Lee JL, Roh SA, Cho DH, Kim SY, Kim YS, Kim JC. Biological characteristics and clinical significance of ITGB1 and $\mathrm{RHOC}$ in patients with recurrent colorectal cancer. Anticancer Res. 2019;39(9):4853-64

46. Yuan YH, Wang HY, Lai Y, Zhong W, Liang WL, Yan FD, Yu Z, Chen JK, Lin Y. Epigenetic inactivation of HOXD10 is associated with human colon cancer via inhibiting the RHOC/AKT/MAPK signaling pathway. Cell Commun Signal. 2019;17(1):9.

47. Griner EM, Dancik GM, Costello JC, Owens C, Guin S, Edwards MG, Brautigan DL, Theodorescu D. RhoC is an unexpected target of RhoGDI2 in prevention of lung colonization of bladder cancer. Mol Cancer Res MCR. 2015;13(3):483-92.

48. liizumi M, Bandyopadhyay S, Pai SK, Watabe M, Hirota S, Hosobe S, Tsukada T, Miura K, Saito K, Furuta E, et al. RhoC promotes metastasis via activation of the Pyk2 pathway in prostate cancer. Can Res. 2008;68(18):7613-20.

49. Yuan Z, Su J, You JF, Wang JL, Cui XL, Zheng J. Correlation of expression of RhoC with invasiveness of prostate cancer cell line PC-3M in vitro. Zhonghua Yi Xue Za Zhi. 2008;88(1):51-5.

50. Ikoma T, Takahashi T, Nagano S, Li YM, Ohno Y, Ando K, Fujiwara T, Fujiwara $\mathrm{H}$, Kosai K. A definitive role of RhoC in metastasis of orthotopic lung cancer in mice. Clin Cancer Res. 2004;10(3):1192-200.

51. Zhou X, Guo X, Chen M, Xie C, Jiang J. HIF-3a promotes metastatic phenotypes in pancreatic cancer by transcriptional regulation of the RhoCROCK1 signaling pathway. Mol Cancer Res MCR. 2018;16(1):124-34.

52. Zhang JG, Zhang DD, Liu Y, Hu JN, Zhang X, Li L, Mu W, Zhu GH, Li Q, Liu GL. RhoC/ROCK2 promotes vasculogenic mimicry formation primarily through ERK/MMPs in hepatocellular carcinoma. Biochim Biophys Acta. 2019;1865(6):1113-25.

53. Schuhmacher J, Heidu S, Balchen T, Richardson JR, Schmeltz C, Sonne J, Schweiker J, Rammensee HG, Thor Straten P, Røder MA, et al. Vaccination against $\mathrm{RhoC}$ induces long-lasting immune responses in patients with prostate cancer: results from a phase I/II clinical trial. J Immunother Cancer. 2020;8(2):e001157.

54. Hakem A, Sanchez-Sweatman O, You-Ten A, Duncan G, Wakeham A, Khokha R, MakTW. RhoC is dispensable for embryogenesis and tumor initiation but essential for metastasis. Genes Dev. 2005;19(17):1974-9.

55. Lawson CD, Ridley AJ. Rho GTPase signaling complexes in cell migration and invasion. J Cell Biol. 2018;217(2):447-57.

56. Voena C, Chiarle R. RHO family GTPases in the biology of lymphoma. Cells. 2019;8(7):646.

57. Hodge RG, Ridley AJ. Regulating Rho GTPases and their regulators. Nat Rev Mol Cell Biol. 2016;17(8):496-510.

58. Aspenström P, Ruusala A, Pacholsky D. Taking Rho GTPases to the next level: the cellular functions of atypical Rho GTPases. Exp Cell Res. 2007;313(17):3673-9.

59. Wheeler AP, Ridley AJ. Why three Rho proteins? RhoA, RhoB, RhoC, and cell motility. Exp Cell Res. 2004;301(1):43-9.

60. Ridley AJ. RhoA, RhoB and RhoC have different roles in cancer cell migration. J Microsc. 2013;251(3):242-9.

61. Yonemura S, Hirao-Minakuchi K, Nishimura Y. Rho localization in cells and tissues. Exp Cell Res. 2004;295(2):300-14.

62. Madaule P, Axel R. A novel ras-related gene family. Cell. 1985:41(1):31-40

63. Madaule P, Axel R, Myers AM. Characterization of two members of the rho gene family from the yeast Saccharomyces cerevisiae. Proc Natl Acad Sci USA. 1987;84(3):779-83.

64. Narumiya S, Thumkeo D. Rho signaling research: history, current status and future directions. FEBS Lett. 2018;592(11):1763-76.

65. Yeramian $P$, Chardin $P$, Madaule $P$, Tavitian A. Nucleotide sequence of human rho cDNA clone 12. Nucleic Acids Res. 1987;15(4):1869.

66. Chardin P, Madaule P, Tavitian A. Coding sequence of human rho cDNAs clone 6 and clone 9. Nucleic Acids Res. 1988;16(6):2717.

67. Chardin P, Boquet P, Madaule P, Popoff MR, Rubin EJ, Gill DM. The mammalian G protein rhoC is ADP-ribosylated by Clostridium botulinum exoenzyme C3 and affects actin microfilaments in Vero cells. EMBO J. 1989:8(4):1087-92.

68. Stasia MJ, Jouan A, Bourmeyster N, Boquet P, Vignais PV. ADP-ribosylation of a small size GTP-binding protein in bovine neutrophils by the C3 exoenzyme of Clostridium botulinum and effect on the cell motility. Biochem Biophys Res Commun. 1991;180(2):615-22.

69. Morris SW, Valentine MB, Kirstein MN, Huebner K. Reassignment of the human ARH9 RAS-related gene to chromosome 1p13-p21. Genomics. 1993;15(3):677-9.

70. Croft DR, Crighton D, Samuel MS, Lourenco FC, Munro J, Wood J, Bensaad K, Vousden KH, Sansom OJ, Ryan KM, et al. p53-mediated transcriptional regulation and activation of the actin cytoskeleton regulatory RhoC to LIMK2 signaling pathway promotes cell survival. Cell Res. 2011;21(4):666-82.

71. Bellovin DI, Simpson KJ, Danilov T, Maynard E, Rimm DL, Oettgen P, Mercurio AM. Reciprocal regulation of RhoA and RhoC characterizes the EMT and identifies RhoC as a prognostic marker of colon carcinoma. Oncogene. 2006;25(52):6959-67.

72. Tian Y, Liu Y, Qu J, Li K, Qin D, Huang A, Tang H. HBV regulated RhoC expression in HepG2.2.15 cells by enhancing its promoter activity. J Basic Microbiol. 2013;53(5):461-8.

73. Qin D, Li K, Qu J, Wang S, Zou C, Sheng Y, Huang A, Tang H. HBx and HBs regulate $\mathrm{RhoC}$ expression by upregulating transcription factor Ets-1. Adv Virol. 2013;158(8):1773-81.

74. Jiang L, Liu X, Kolokythas A, Yu J, Wang A, Heidbreder CE, Shi F, Zhou X. Downregulation of the Rho GTPase signaling pathway is involved in the microRNA-138-mediated inhibition of cell migration and invasion in tongue squamous cell carcinoma. Int J Cancer. 2010;127(3):505-12.

75. Islam M, Datta J, Lang JC, Teknos TN. Down regulation of RhoC by microRNA-138 results in de-activation of FAK, Src and Erk1/2 signaling pathway in head and neck squamous cell carcinoma. Oral Oncol. 2014:50(5):448-56. 
76. Liu BL, Sun KX, Zong ZH, Chen S, Zhao Y. MicroRNA-372 inhibits endometrial carcinoma development by targeting the expression of the Ras homolog gene family member C (RhoC). Oncotarget. 2016;7(6):6649-64.

77. Ma L, Teruya-Feldstein J, Weinberg RA. Tumour invasion and metastasis initiated by microRNA-10b in breast cancer. Nature. 2007;449(7163):682-8.

78. Knirsh R, Ben-Dror I, Modai S, Shomron N, Vardimon L. MicroRNA 10b promotes abnormal expression of the proto-oncogene c-Jun in metastatic breast cancer cells. Oncotarget. 2016;7(37):59932-44.

79. Wang YF, Li Z, Zhao XH, Zuo XM, Zhang Y, Xiao YH, Li J, Peng ZH. MicroRNA-10b is upregulated and has an invasive role in colorectal cancer through enhanced Rhoc expression. Oncol Rep. 2015;33(3):1275-83.

80. Sasayama T, Nishihara M, Kondoh T, Hosoda K, Kohmura E. MicroRNA$10 \mathrm{~b}$ is overexpressed in malignant glioma and associated with tumor invasive factors, UPAR and RhoC. Int J Cancer. 2009;125(6):1407-13.

81. Sang XB, Zong ZH, Wang LL, Wu DD, Chen S, Liu BL, Zhao Y. E2F-1 targets miR-519d to regulate the expression of the ras homolog gene family member C. Oncotarget. 2017;8(9):14777-93.

82. Zhou W, Zhang C, Jiang H, Zhang Z, Xie L, He X. MiR-493 suppresses the proliferation and invasion of gastric cancer cells by targeting RhoC. Iran J Basic Med Sci. 2015;18(10):1027-33.

83. Yau WL, Lam CS, Ng L, Chow AK, Chan ST, Chan JY, Wo JY, Ng KT, Man $K$, Poon RT, et al. Over-expression of miR-106b promotes cell migration and metastasis in hepatocellular carcinoma by activating epithelialmesenchymal transition process. PLoS ONE. 2013;8(3):e57882.

84. Chen S, Chen X, Xiu YL, Sun KX, Zhao Y. Inhibition of ovarian epithelial carcinoma tumorigenesis and progression by microRNA 106b mediated through the RhoC pathway. PLoS ONE. 2015;10(5):e0125714.

85. Wang LL, Zong ZH, Liu Y, Guan X, Chen S, Zhao Y. CircRhoC promotes tumorigenicity and progression in ovarian cancer by functioning as a miR-302e sponge to positively regulate VEGFA. J Cell Mol Med. 2019;23(12):8472-81.

86. Xie SL, Wang M, Du XH, Zhao ZW, Lv GY. miR-455 inhibits HepG2 cell proliferation and promotes apoptosis by targeting RhoC. Mol Biol. 2020;54(1):69-77.

87. Zang HL, Ji FJ, Ju HY, Tian XF. Circular RNA AKT3 governs malignant behaviors of esophageal cancer cells by sponging miR-17-5p. World J Gastroenterol. 2021;27(3):240-54.

88. Shao S, Hu Q, Wu W, Wang M, Huang J, Zhao X, Tang G, Liang T. Tumortriggered personalized microRNA cocktail therapy for hepatocellular carcinoma. Biomater Sci. 2020;8(23):6579-91.

89. Suwa H, Ohshio G, Imamura T, Watanabe G, Arii S, Imamura M, Narumiya S, Hiai H, Fukumoto M. Overexpression of the rhoC gene correlates with progression of ductal adenocarcinoma of the pancreas. $\mathrm{Br} J$ Cancer. 1998:77(1):147-52.

90. Wang W, Yang LY, Huang GW, Yang ZL, Lu WQ, Peng JX, Yang JQ. Overexpression of the RhoC gene correlates with invasion and metastasis of hepatocellular carcinoma. Zhonghua zhong liu za zhi Chin J Oncol. 2004;26(5):279-82.

91. Fritz G, Brachetti C, Bahlmann F, Schmidt M, Kaina B. Rho GTPases in human breast tumours: expression and mutation analyses and correlation with clinical parameters. Br J Cancer. 2002;87(6):635-44.

92. Wang $L$, Yang $L$, Luo $Y$, Zheng Y. A novel strategy for specifically downregulating individual Rho GTPase activity in tumor cells. J Biol Chem. 2003;278(45):44617-25.

93. Sloan CM, Quinn CV, Peters JP, Farley J, Goetzinger C, Wernli M, DeMali KA, Ellerbroek SM. Divergence of Rho residue 43 impacts GEF activity. Small GTPases. 2012;3(1):15-22.

94. Wu D, Asiedu M, Wei Q. Myosin-interacting guanine exchange factor (MyoGEF) regulates the invasion activity of MDA-MB-231 breast cancer cells through activation of RhoA and RhoC. Oncogene. 2009;28(22):2219-30.

95. Patel A, Williams-Perez S, Peyton N, Reicks A, Buzick J, Farley J, Shirar S, Ellerbroek SM. Arg188 drives RhoC membrane binding. Small GTPases. 2017:8(2):114-21.

96. Campanale JP, Sun TY, Montell DJ. Development and dynamics of cell polarity at a glance. J Cell Sci. 2017;130(7):1201-7.

97. Ridley AJ, Schwartz MA, Burridge K, Firtel RA, Ginsberg MH, Borisy G, Parsons JT, Horwitz AR. Cell migration: integrating signals from front to back. Science. 2003;302(5651):1704.
98. Schaks M, Giannone G, Rottner K. Actin dynamics in cell migration. Essays Biochem. 2019;63(5):483-95.

99. Mayor R, Etienne-Manneville S. The front and rear of collective cell migration. Nat Rev Mol Cell Biol. 2016;17(2):97-109.

100. Svitkina T. The actin cytoskeleton and actin-based motility. Cold Spring Harb Perspect Biol. 2018;10(1):a018267.

101. Bravo-Cordero JJ, Magalhaes MAO, Eddy RJ, Hodgson L, Condeelis J. Functions of cofilin in cell locomotion and invasion. Nat Rev Mol Cell Biol. 2013;14(7):405-15.

102. Etienne-Manneville S. Microtubules in cell migration. Annu Rev Cell Dev Biol. 2013;29(1):471-99.

103. van Helden SFG, Anthony EC, Dee R, Hordijk PL. Rho GTPase expression in human myeloid cells. PLoS ONE. 2012;7(8):e42563-e42563.

104. Zeng YF, Xiao YS, Liu Y, Luo XJ, Wen LD, Liu Q, Chen M. Formin-like 3 regulates RhoC/FAK pathway and actin assembly to promote cell invasion in colorectal carcinoma. World J Gastroenterol. 2018;24(34):3884-97.

105. Zaritsky A, Tseng YY, Rabadán MA, Krishna S, Overholtzer M, Danuser G, Hall A. Diverse roles of guanine nucleotide exchange factors in regulating collective cell migration. J Cell Biol. 2017;216(6):1543-56.

106. Mitin N, Rossman KL, Currin R, Anne S, Marshall TW, Bear JE, Bautch VL, Der CJ. The RhoGEF TEM4 regulates endothelial cell migration by suppressing actomyosin contractility. PLoS ONE. 2013;8(6):e66260.

107. Zhao Z, Liu K, Tian X, Sun M, Wei N, Zhu X, Yang H, Wang T, Jiang $G$, Chen K. Effects of RhoC downregulation on the angiogenesis characteristics of myeloma vascular endothelial cells. Cancer Med. 2019;8(7):3502-10.

108. Vega FM, Fruhwirth G, Ng T, Ridley AJ. RhoA and RhoC have distinct roles in migration and invasion by acting through different targets. J Cell Biol. 2011;193(4):655-65.

109. MacGrath SM, Koleske AJ. Invadopodia: RhoC runs rings around cofilin. Curr Biol CB. 2011:21(8):R280-282.

110. Gou WF, Zhao Y, Lu H, Yang XF, Xiu YL, Zhao S, Liu JM, Zhu ZT, Sun HZ, Liu YP, et al. The role of RhoC in epithelial-to-mesenchymal transition of ovarian carcinoma cells. BMC Cancer. 2014;14:477.

111. Bravo-Cordero JJ, Oser M, Chen X, Eddy R, Hodgson L, Condeelis J. A novel spatiotemporal RhoC activation pathway locally regulates cofilin activity at invadopodia. Curr Biol CB. 2011;21(8):635-44.

112. Bagnato A, Rosanò L. Endothelin-1 receptor drives invadopodia: exploiting how $\beta$-arrestin-1 guides the way. Small GTPases. 2018;9(5):394-8.

113. Semprucci E, Tocci P, Cianfrocca R, Sestito R, Caprara V, Veglione M, Castro VD, Spadaro F, Ferrandina G, Bagnato A, et al. Endothelin A receptor drives invadopodia function and cell motility through the $\beta$-arrestin/PDZ-RhoGEF pathway in ovarian carcinoma. Oncogene. 2016;35(26):3432-42.

114. Willmer T, Contu L, Blatch GL, Edkins AL. Knockdown of Hop downregulates $\mathrm{RhoC}$ expression, and decreases pseudopodia formation and migration in cancer cell lines. Cancer Lett. 2013;328(2):252-60.

115. Bravo-Cordero JJ, Hodgson L, Condeelis JS. Spatial regulation of tumor cell protrusions by RhoC. Cell Adh Migr. 2014;8(3):263-7.

116. Wrighton KH. Cytoskeleton: RhoC invades cofilin's space. Nat Rev Mol Cell Biol. 2011;12(6):346-7

117. Zhu Y, Xu Y, Chen T, Zhang Y, Ma Q, Rauniyar S, Wang L, Shi H. TSG101 Promotes the proliferation, migration, and invasion of human glioma cells by regulating the AKT/GSK3 $\beta / \beta$-catenin and RhoC/Cofilin pathways. Mol Neurobiol. 2021;58(5):2118-32.

118. Martín-Villar E, Borda-d'Agua B, Carrasco-Ramirez P, Renart J, Parsons M, Quintanilla M, Jones GE. Podoplanin mediates ECM degradation by squamous carcinoma cells through control of invadopodia stability. Oncogene. 2015;34(34):4531-44.

119. Sequeira L, Dubyk CW, Riesenberger TA, Cooper CR, van Golen KL. Rho GTPases in PC-3 prostate cancer cell morphology, invasion and tumor cell diapedesis. Clin Exp Metas. 2008;25(5):569-79.

120. Jacquemet G, Humphries MJ. IQGAP1 is a key node within the small GTPase network. Small GTPases. 2013;4(4):199-207.

121. Peng X, Wang T, Gao H, Yue X, Bian W, Mei J, Zhang Y. The interplay between IQGAP1 and small GTPases in cancer metastasis. Biomed Pharmacother Biomed Pharmacother. 2021;135:111243.

122. Casteel DE, Turner S, Schwappacher R, Rangaswami H, Su-Yuo J, Zhuang S, Boss GR, Pilz RB. Rho isoform-specific interaction with IQGAP1 promotes breast cancer cell proliferation and migration. J Biol Chem. 2012;287(45):38367-78. 
123. Bravo-Cordero JJ, Sharma VP, Roh-Johnson M, Chen X, Eddy R, Condeelis J, Hodgson L. Spatial regulation of RhoC activity defines protrusion formation in migrating cells. J Cell Sci. 2013;126(Pt 15):3356-69.

124. Conway JRW, Jacquemet G. Cell matrix adhesion in cell migration. Essays Biochem. 2019;63(5):535-51.

125. Goicoechea SM, Awadia S, Garcia-Mata R. I'm coming to GEF you: regulation of RhoGEFs during cell migration. Cell Adh Migr. 2014;8(6):535-49.

126. De Pascalis C, Etienne-Manneville S. Single and collective cell migration: the mechanics of adhesions. Mol Biol Cell. 2017;28(14):1833-46.

127. Wu M, Wu ZF, Rosenthal DT, Rhee EM, Merajver SD. Characterization of the roles of RHOC and RHOA GTPases in invasion, motility, and matrix adhesion in inflammatory and aggressive breast cancers. Cancer. 2010;116(11 Suppl):2768-82.

128. Wu M, Wu ZF, Kumar-Sinha C, Chinnaiyan A, Merajver SD. RhoC induces differential expression of genes involved in invasion and metastasis in MCF10A breast cells. Breast Cancer Res Treat. 2004;84(1):3-12.

129. Joglekar M, Elbezanti WO, Weitzman MD, Lehman HL, van Golen KL. Caveolin-1 mediates inflammatory breast cancer cell invasion via the Akt1 pathway and RhoC GTPase. J Cell Biochem. 2015;116(6):923-33.

130. Lin M, DiVito MM, Merajver SD, Boyanapalli M, van Golen KL. Regulation of pancreatic cancer cell migration and invasion by RhoC GTPase and caveolin-1. Mol Cancer. 2005;4(1):21.

131. Thomas S, Overdevest JB, Nitz MD, Williams PD, Owens CR, SanchezCarbayo M, Frierson HF, Schwartz MA, Theodorescu D. Src and caveolin-1 reciprocally regulate metastasis via a common downstream signaling pathway in bladder cancer. Can Res. 2011;71(3):832-41.

132. Li NF, Gemenetzidis E, Marshall FJ, Davies D, Yu Y, Frese K, Froeling FE, Woolf AK, Feakins RM, Naito Y, et al. RhoC interacts with integrin a $5 \beta 1$ and enhances its trafficking in migrating pancreatic carcinoma cells. PLOS ONE. 2013:8(12):e81575.

133. Arpaia E, Blaser H, Quintela-Fandino M, Duncan G, Leong HS, Ablack A, Nambiar SC, Lind EF, Silvester J, Fleming CK, et al. The interaction between caveolin-1 and Rho-GTPases promotes metastasis by controlling the expression of alpha5-integrin and the activation of Src Ras and Erk. Oncogene. 2012;31(7):884-96.

134. Crosas-Molist E, Bertran E, Rodriguez-Hernandez I, Herraiz C, Cantelli G, Fabra Ä, Sanz-Moreno V, Fabregat I. The NADPH oxidase NOX4 represses epithelial to amoeboid transition and efficient tumour dissemination. Oncogene. 2017;36(21):3002-14.

135. Balzer EM, Konstantopoulos K. Intercellular adhesion: mechanisms for growth and metastasis of epithelial cancers. Wiley Interdiscip Rev Syst Biol Med. 2012;4(2):171-81.

136. Reinhard NR, van Helden SF, Anthony EC, Yin T, Wu YI, Goedhart J, Gadella TW, Hordijk PL. Spatiotemporal analysis of RhoA/B/C activation in primary human endothelial cells. Sci Rep. 2016;6:25502.

137. Tripathi V, Popescu NC, Zimonjic DB. DLC1 induces expression of E-cadherin in prostate cancer cells through Rho pathway and suppresses invasion. Oncogene. 2014;33(6):724-33.

138. Iwanicki MP, Vomastek T, Tilghman RW, Martin KH, Banerjee J, Wedegaertner PB, Parsons JT. FAK, PDZ-RhoGEF and ROCKII cooperate to regulate adhesion movement and trailing-edge retraction in fibroblasts. J Cell Sci. 2008:121(6):895-905.

139. Chang GH, Lay AJ, Ting KK, Zhao Y, Coleman PR, Powter EE, FormazPreston A, Jolly CJ, Bower NI, Hogan BM, et al. ARHGAP18: an endogenous inhibitor of angiogenesis, limiting tip formation and stabilizing junctions. Small GTPases. 2014;5(3):1-15.

140. Sahai E, Marshall CJ. ROCK and Dia have opposing effects on adherens junctions downstream of Rho. Nat Cell Biol. 2002;4(6):408-15.

141. Lammers M, Meyer S, Kühlmann D, Wittinghofer A. Specificity of interactions between mDia isoforms and Rho proteins. J Biol Chem. 2008;283(50):35236-46.

142. Narumiya S, Tanji M, Ishizaki T. Rho signaling, ROCK and mDia1, in transformation, metastasis and invasion. Cancer Metastasis Rev. 2009;28(1-2):65-76.

143. Zheng Y, Nan H, Liu Y, Fan Q, Wang X, Liu R, Liu L, Ye F, Sun B, Jiao Y. Modeling cell migration regulated by cell extracellular-matrix micromechanical coupling. Phys Rev E. 2019;100(4-1):043303.

144. Unbekandt M, Olson MF. The actin-myosin regulatory MRCK kinases: regulation, biological functions and associations with human cancer. $J$ Mol Med (Berl). 2014;92(3):217-25.
145. Jackson B, Peyrollier K, Pedersen E, Basse A, Karlsson R, Wang Z, Lefever T, Ochsenbein AM, Schmidt G, Aktories K, et al. RhoA is dispensable for skin development, but crucial for contraction and directed migration of keratinocytes. Mol Biol Cell. 2011;22(5):593-605.

146. Aspenström P, Fransson A, Saras J. Rho GTPases have diverse effects on the organization of the actin filament system. Biochem J. 2004;377(Pt 2):327-37.

147. Durkin CH, Leite F, Cordeiro JV, Handa Y, Arakawa Y, Valderrama F, Way M. RhoD inhibits RhoC-ROCK-dependent cell contraction via PAK6. Dev Cell. 2017;41(3):315-329.e317.

148. Valderrama F, Cordeiro JV, Schleich S, Frischknecht F, Way M. Vaccinia virus-induced cell motility requires F11L-mediated inhibition of RhoA signaling. Science. 2006;311(5759):377-81.

149. Korkina O, Dong Z, Marullo A, Warshaw G, Symons M, Ruggieri R. The MLK-related kinase (MRK) is a novel RhoC effector that mediates lysophosphatidic acid (LPA)-stimulated tumor cell invasion. J Biol Chem. 2013;288(8):5364-73.

150. Xia D, Stull JT, Kamm KE. Myosin phosphatase targeting subunit 1 affects cell migration by regulating myosin phosphorylation and actin assembly. Exp Cell Res. 2005;304(2):506-17.

151. Hetmanski JHR, de Belly H, Busnelli I, Waring T, Nair RV, Sokleva V, Dobre O, Cameron A, Gauthier N, Lamaze C, et al. Membrane tension orchestrates rear retraction in matrix-directed cell migration. Dev Cell. 2019;51(4):460-475.e410.

152. Ridley AJ. Life at the leading edge. Cell. 2011;145(7):1012-22.

153. Fonseca AV, Freund D, Bornhäuser M, Corbeil D. Polarization and migration of hematopoietic stem and progenitor cells rely on the RhoA/ROCK I pathway and an active reorganization of the microtubule network. J Biol Chem. 2010;285(41):31661-71.

154. Worthylake RA, Burridge K. RhoA and ROCK promote migration by limiting membrane protrusions. J Biol Chem. 2003;278(15):13578-84.

155. Petrie RJ, Yamada KM. Multiple mechanisms of $3 \mathrm{D}$ migration: the origins of plasticity. Curr Opin Cell Biol. 2016:42:7-12.

156. Gong X, Didan Y, Lock JG, Strömblad S. KIF13A-regulated RhoB plasma membrane localization governs membrane blebbing and blebby amoeboid cell migration. The EMBO J. 2018;37(17):e98994.

157. Friedl P, Sahai E, Weiss S, Yamada KM. New dimensions in cell migration. Nat Rev Mol Cell Biol. 2012;13(11):743-7.

158. Kitzing TM, Wang Y, Pertz O, Copeland JW, Grosse R. Formin-like 2 drives amoeboid invasive cell motility downstream of RhoC. Oncogene. 2010;29(16):2441-8.

159. Sanz-Moreno V, Marshall CJ. The plasticity of cytoskeletal dynamics underlying neoplastic cell migration. Curr Opin Cell Biol. 2010;22(5):690-6.

160. Even-Ram S, Yamada KM. Cell migration in 3D matrix. Curr Opin Cell Biol. 2005; 17(5):524-32.

161. Agarwal P, Zaidel-Bar R. Diverse roles of non-muscle myosin II contractility in 3D cell migration. Essays Biochem. 2019;63(5):497-508.

162. Lämmermann T, Sixt M. Mechanical modes of "amoeboid" cell migration. Curr Opin Cell Biol. 2009;21(5):636-44.

163. Lämmermann T, Sixt M. Mechanical modes of 'amoeboid'cell migration. Curr Opin Cell Biol. 2009;21(5):636-44.

164. Stoletov K, Montel V, Lester RD, Gonias SL, Klemke R. High-resolution imaging of the dynamic tumor cell vascular interface in transparent zebrafish. Proc Natl Acad Sci USA. 2007;104(44):17406-11.

165. López-Luque J, Bertran E, Crosas-Molist E, Maiques O, Malfettone A, Caja L, Serrano T, Ramos E, Sanz-Moreno V, Fabregat I. Downregulation of Epidermal Growth Factor Receptor in hepatocellular carcinoma facilitates Transforming Growth Factor- $\beta$-induced epithelial to amoeboid transition. Cancer Lett. 2019;464:15-24.

166. Lehman HL, Dashner EJ, Lucey M, Vermeulen P, Dirix L, Van Laere S, van Golen KL. Modeling and characterization of inflammatory breast cancer emboli grown in vitro. Int J Cancer. 2013;132(10):2283-94.

167. Yamada KM, Collins JW, Cruz Walma DA, Doyle AD, Morales SG, Lu J, Matsumoto K, Nazari SS, Sekiguchi R, Shinsato Y, et al. Extracellular matrix dynamics in cell migration, invasion and tissue morphogenesis. Int J Exp Pathol. 2019;100(3):144-52.

168. Petrie RJ, Koo H, Yamada KM. Generation of compartmentalized pressure by a nuclear piston governs cell motility in a 3D matrix. Science. 2014;345(6200):1062-5. 
169. Serrano-Alcalde F, García-Aznar JM, Gómez-Benito MJ. Cell biophysical stimuli in lobodopodium formation: a computer based approach. Comput Methods Biomech Biomed Eng. 2020;24(5):496-505.

170. Petrie RJ, Gavara N, Chadwick RS, Yamada KM. Nonpolarized signaling reveals two distinct modes of 3D cell migration. J Cell Biol. 2012;197(3):439-55.

171. Sao K, Jones TM, Doyle AD, Maity D, Schevzov G, Chen Y, Gunning PW, Petrie RJ. Myosin II governs intracellular pressure and traction by distinct tropomyosin-dependent mechanisms. Mol Biol Cell. 2019;30(10):1170-81.

172. Wolf K, Mazo I, Leung H, Engelke K, von Andrian UH, Deryugina El, Strongin AY, Bröcker EB, Friedl P. Compensation mechanism in tumor cell migration: mesenchymal-amoeboid transition after blocking of pericellular proteolysis. J Cell Biol. 2003;160(2):267-77.

173. Riching KM, Keely PJ. Rho family GTPases: making it to the third dimension. Int J Biochem Cell Biol. 2015;59:111-5.

174. Kim JG, Islam R, Cho JY, Jeong H, Cap KC, Park Y, Hossain AJ, Park JB. Regulation of RhoA GTPase and various transcription factors in the RhoA pathway. J Cell Physiol. 2018;233(9):6381-92.

175. Ridley AJ, Hall A. The small GTP-binding protein rho regulates the assembly of focal adhesions and actin stress fibers in response to growth factors. Cell. 1992;70(3):389-99.

176. Pertz O, Hodgson L, Klemke RL, Hahn KM. Spatiotemporal dynamics of RhoA activity in migrating cells. Nature. 2006:440(7087):1069-72.

177. Vega FM, Colomba A, Reymond N, Thomas M, Ridley AJ. RhoB regulates cell migration through altered focal adhesion dynamics. Open Biol. 2012:2(5):120076.

178. Ju JA, Gilkes DM. RhoB: team oncogene or team tumor suppressor? Genes. 2018;9(2):67.

179. Zhao ZH, Tian Y, Yang JP, Zhou J, Chen KS. RhoC, vascular endothelial growth factor and microvascular density in esophageal squamous cell carcinoma. World J Gastroenterol. 2015;21(3):905-12.

180. Ridley AJ, Paterson HF, Johnston CL, Diekmann D, Hall A. The small GTP-binding protein rac regulates growth factor-induced membrane ruffling. Cell. 1992;70(3):401-10.

181. Payapilly A, Malliri A. Compartmentalisation of RAC1 signalling. Curr Opin Cell Biol. 2018;54:50-6.

182. Hsu AP, Donkó A, Arrington ME, Swamydas M, Fink D, Das A, Escobedo $\mathrm{O}$, Bonagura V, Szabolcs P, Steinberg HN, et al. Dominant activating RAC2 mutation with lymphopenia, immunodeficiency, and cytoskeletal defects. Blood. 2019;133(18):1977-88.

183. Mahankali M, Peng HJ, Cox D, Gomez-Cambronero J. The mechanism of cell membrane ruffling relies on a phospholipase D2 (PLD2), Grb2 and Rac2 association. Cell Signal. 2011;23(8):1291-8.

184. Joyce PL, Cox AD. Rac1 and Rac3 are targets for geranylgeranyltransferase I inhibitor-mediated inhibition of signaling, transformation, and membrane ruffling. Can Res. 2003;63(22):7959-67.

185. Hajdo-Milasinović A, Ellenbroek SI, van Es S, van der Vaart B, Collard JG. Rac1 and Rac3 have opposing functions in cell adhesion and differentiation of neuronal cells. J Cell Sci. 2007;120(Pt 4):555-66.

186. Gauthier-Rouvière C, Vignal E, Mériane M, Roux P, Montcourier P, Fort P. RhoG GTPase controls a pathway that independently activates Rac1 and Cdc42Hs. Mol Biol Cell. 1998;9(6):1379-94.

187. Kozma R, Ahmed S, Best A, Lim L. The Ras-related protein Cdc42Hs and bradykinin promote formation of peripheral actin microspikes and filopodia in Swiss 3T3 fibroblasts. Mol Cell Biol. 1995;15(4):1942-52.

188. Herrington KA, Trinh AL, Dang C, O'Shaughnessy E, Hahn KM, Gratton E, Digman MA, Sütterlin C. Spatial analysis of Cdc42 activity reveals a role for plasma membrane-associated $\mathrm{Cdc} 42$ in centrosome regulation. $\mathrm{Mol}$ Biol Cell. 2017:28(15):2135-45.

189. Eelen G, Dubois C, Cantelmo AR, Goveia J, Brüning U, DeRan M, Jarugumilli G, van Rijssel J, Saladino G, Comitani F, et al. Role of glutamine synthetase in angiogenesis beyond glutamine synthesis. Nature. 2018;561(7721):63-9.

190. Wilson E, Leszczynska K, Poulter NS, Edelmann F, Salisbury VA, Noy PJ, Bacon A, Rappoport JZ, Heath JK, Bicknell R, et al. RhoJ interacts with the GIT-PIX complex and regulates focal adhesion disassembly. J Cell Sci. 2014;127(Pt 14):3039-51.

191. Kilisch M, Mayer S, Mitkovski M, Roehse H, Hentrich J, Schwappach B, Papadopoulos T. A GTPase-induced switch in phospholipid affinity of collybistin contributes to synaptic gephyrin clustering. J Cell Sci. 2020;133(2):jcs232835.

192. Neudauer CL, Joberty G, Tatsis N, Macara IG. Distinct cellular effects and interactions of the Rho-family GTPase TC10. Current Biol CB. 1998:8(21):1151-60

193. Blom M, Reis K, Heldin J, Kreuger J, Aspenström P. The atypical Rho GTPase RhoD is a regulator of actin cytoskeleton dynamics and directed cell migration. Exp Cell Res. 2017;352(2):255-64.

194. Pellegrin S, Mellor H. The Rho family GTPase Rif induces filopodia through mDia2. Curr Biol CB. 2005;15(2):129-33.

195. Fan L, Mellor H. The small Rho GTPase Rif and actin cytoskeletal remodelling. Biochem Soc Trans. 2012;40(1):268-72.

196. Kishimoto M, Matsuda T, Yanase S, Katsumi A, Suzuki N, Ikejiri M, Takagi A, Ikawa M, Kojima T, Kunishima S, et al. Rhof promotes murine marginal zone B cell development. Nagoya J Med Sci. 2014;76(3-4):293-305.

197. Ellis $\mathrm{S}$, Mellor $\mathrm{H}$. The novel Rho-family GTPase rif regulates coordinated actin-based membrane rearrangements. Curr Biol CB. 2000;10(21):1387-90.

198. Tajadura-Ortega V, Garg R, Allen R, Owczarek C, Bright MD, Kean S, Mohd-Noor A, Grigoriadis A, Elston TC, Hahn KM, et al. An RNAi screen of Rho signalling networks identifies $\mathrm{RhoH}$ as a regulator of Rac1 in prostate cancer cell migration. BMC Biol. 2018;16(1):29.

199. Ahmad Mokhtar AM, Hashim IF, Mohd Zaini Makhtar M, Salikin NH, Amin-Nordin S. The role of RhoH in TCR signalling and its involvement in diseases. Cells. 2021;10(4):950.

200. Mouly L, Gilhodes J, Lemarié A, Cohen-Jonathan Moyal E, Toulas C, Favre G, Sordet O, Monferran S. The RND1 small GTPase: main functions and emerging role in oncogenesis. Int J Mol Sci. 2019;20(15):3612.

201. Katoh H, Harada A, Mori K, Negishi M. Socius is a novel Rnd GTPaseinteracting protein involved in disassembly of actin stress fibers. Mol Cell Biol. 2002;22(9):2952-64.

202. Riou P, Villalonga P, Ridley AJ. Rnd proteins: multifunctional regulators of the cytoskeleton and cell cycle progression. BioEssays News Rev Mol Cell Dev Biol. 2010;32(11):986-92.

203. Tanaka H, Katoh H, Negishi M. Pragmin, a novel effector of Rnd2 GTPase stimulates RhoA activity. J Biol Chem. 2006:281 (15):10355-64.

204. Riento K, Totty N, Villalonga P, Garg R, Guasch R, Ridley AJ. RhoE function is regulated by ROCK I-mediated phosphorylation. EMBO J. 2005;24(6):1170-80.

205. Dart AE, Box GM, Court W, Gale ME, Brown JP, Pinder SE, Eccles SA, Wells CM. PAK4 promotes kinase-independent stabilization of RhoU to modulate cell adhesion. J Cell Biol. 2015;211(4):863-79.

206. Chuang YY, Valster A, Coniglio SJ, Backer JM, Symons M. The atypical Rho family GTPase Wrch-1 regulates focal adhesion formation and cell migration. J Cell Sci. 2007;120(Pt 11):1927-34.

207. Faure S, Fort P. Atypical RhoV and RhoU GTPases control development of the neural crest. Small GTPases. 2015;6(4):174-7.

208. Hodge RG, Ridley AJ. Regulation and functions of RhoU and RhoV. Small GTPases. 2020:11(1):8-15.

209. McKinnon CM, Mellor H. The tumor suppressor RhoBTB1 controls Golgi integrity and breast cancer cell invasion through METTL7B. BMC Cancer. 2017;17(1):145.

210. Berthold J, Schenkova K, Rivero F. Rho GTPases of the RhoBTB subfamily and tumorigenesis. Acta Pharmacol Sin. 2008;29(3):285-95.

\section{Publisher's Note}

Springer Nature remains neutral with regard to jurisdictional claims in published maps and institutional affiliations. 